\title{
A Model for Development Planning Process Based on the Sustainable Development Approach in the Iranian Oil Industry
}

Zahra Banasadegh ${ }^{1}$ Ph.D. Student of Public Administration, Institute for Management and Planning Studies, Tehran, Iran.

Shamssosadat Zahedi ${ }^{2}$ Professor, Faculty of Management and Accounting, Allameh Tabataba'i University, Tehran, Iran. (Corresponding Author)

Gholamali Farjadi ${ }^{3}$ Associate Professor of Economics, Institute for Management and Planning Studies, Tehran, Iran.

\begin{abstract}
The complexity and extent of sustainable development concept calls for the capability to apply planning tools to introduce optimal relationship among all aspects of development and to materialize all principles of sustainability. Related literature and sustainable development processes in some countries, as well as 30 companies affiliated to the Iranian Oil Industry, which were all practicing sustainable development approach, were studied to reach a model for sustainable development. Results show that the outcomes of the six main steps or processes (starting with the stage of planning, stakeholders' participation, preparing planning draft, formulating the vision, preparing outcomes framework, and planning for implementation), as well as fourteen secondary steps and processes (creating the core of planning, preparing the schedule, preparing instructions, assigning planning stakeholders, identifying problems on the basis of geographical regions, identifying problems related to sustainable development, assigning sustainable development stakeholders, identifying problem solving resources, formulating the vision, setting objectives, determining outcomes, formulating indexes, determining implementation resources, and designating responsibilities) are at a favorable level. However, only the two secondary processes of formulating indexes and designating administrative responsibilities need improvement.
\end{abstract}

Keywords: Evaluation, Development, Planning, Process, Sustainable Development Approach.

1.z.banasadegh@imps.ac.ir

2. szahedi@atu.ac.ir

3.gh.farjadi@imps.ac.ir 
عنوان مقاله: طراحى مدل فرايند برنامدريزى توسعه در صنعت نفت با رويكرد توسعه يايدار

$$
\text { فرجادى بناصادق' ـ شمسالسادات زاهدى'_غلامعلى }
$$

مقاله يُوهشى

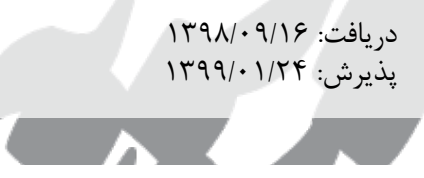

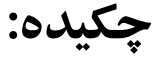

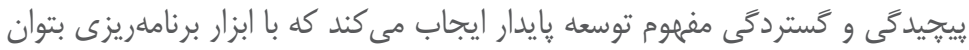

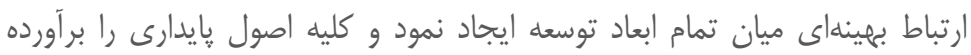

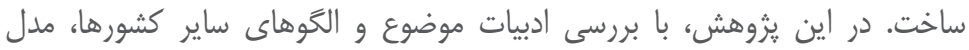

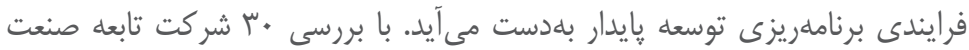

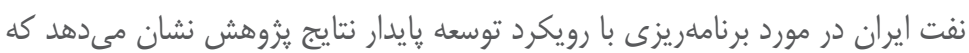

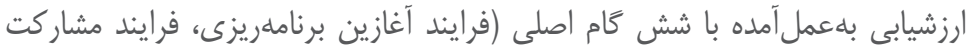

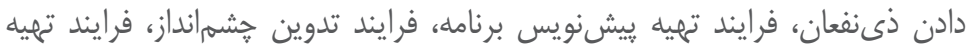

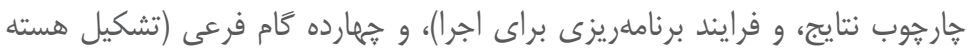

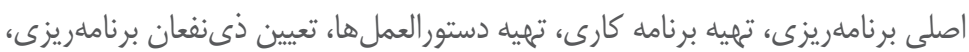

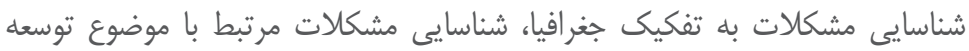

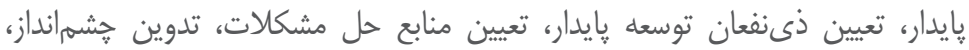

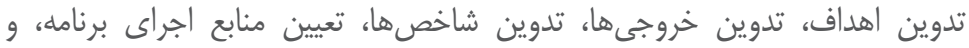

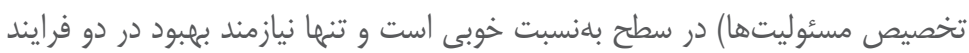
فرعى تدوين شاخصها و تعيين مسئوليتهاى اجرايى است.

كليدوازهها: ارزشابى، توسعه، برنامهريزى، فرايند، رويكرد توسعه

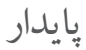

ا. دانشجوى دكترى مديريت دولتى گرايش تطبيقى و توسعه، موسسه عالى آموزش و بُروهش مديريت و z.banasadegh@imps.ac.ir برنامهريزى r. r. استاد دانشكده مديريت و حسابدارى، دانشكاه علامه طباطبايى (نويسنده مسئول).

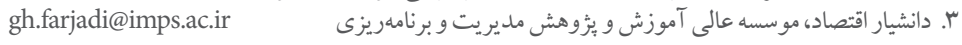




\section{مقدمه}

با خارج شدن سازمانهاى امروزى از يك نهاد صرفاً ادارى و اقتصادى، لزوم آكاهى آنها به محيط اجتماعى احساس مىشود. دانش سياسى و اجتماعى لازمه مديريت توسعه امروز است و

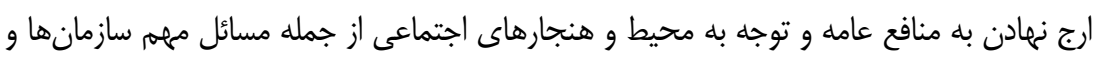

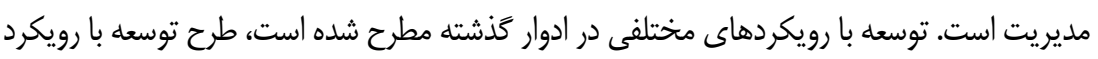

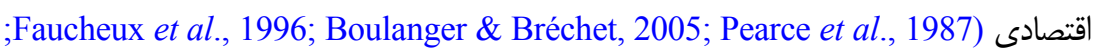
Marinova \& McGrath, 2005; Todorov \& Marinova, 2009

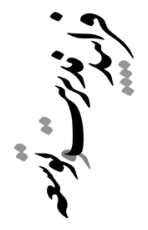
،(IPCC, 2007; Speth, 2004; Litfin, 1994; Turco et al., 1983; Meadows et al., 1972) Pearce et al., 1987; Todorov \& Marinova, 2009; Marinova) رويكرد اجتماعى - فرهنگى Faucheux et al., 1996; Karlsson, 1999;) (\& McGrath, 2005

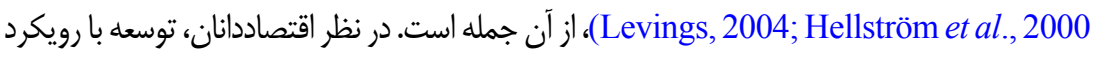
اقتصادى به معناى تخصيص منابع كمياب و قدرتهاى مولد ملّى به افزايش ذخيره ثروت ملّى و نظّ

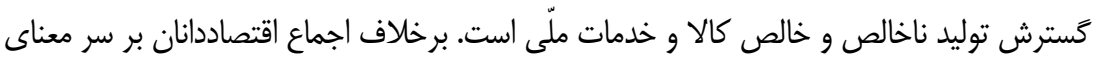
توسعه اقتصادى، دانشمندان سياسى تعابير متفاوتى از توسعه سياسى ارائه مى كنند. دانشمندان سياسى لماسى

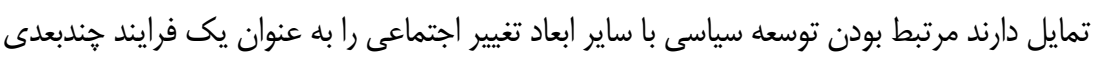
مورد توجه قرار دهند (Heady, 2001).

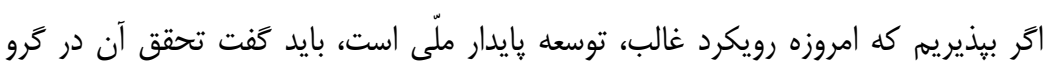

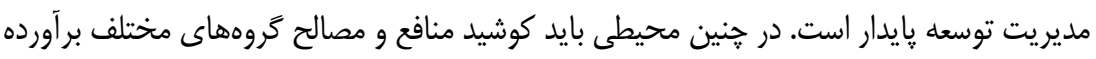

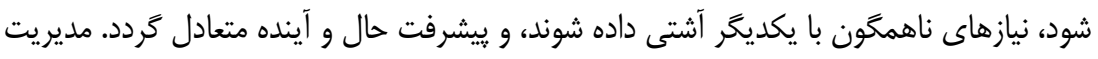

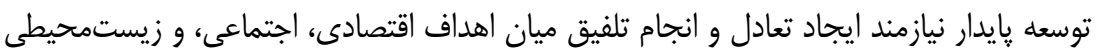

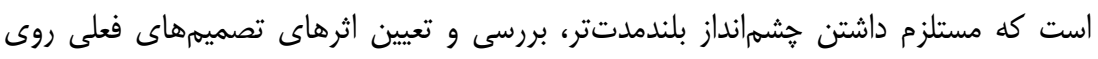
نسلهاى آتى، وضع قوانين، مقررات، همكارىهاى ضرورى محلى، ملّى، منطقلهاى و جهانى، عقد

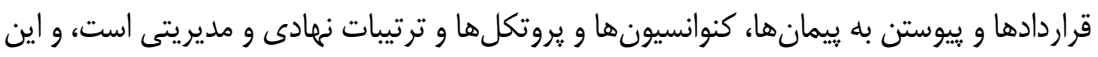
خود محيط و بُعد اصلى بعدى را مشخص مى كند كه همان محيط سياسى و بعد سياسى است. به به به

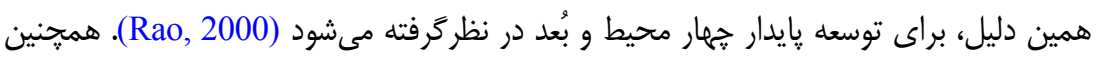


دستيابى به اين موضوعات، ايجاد ساختارهاى هدايتى و حمايتى و تثبيت آن ها مستلزم وضع اهداف

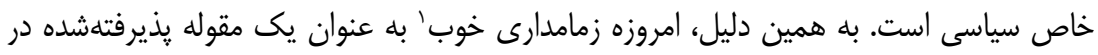

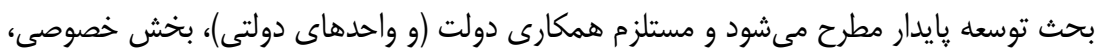
و نهادهاى مدنى و مردم در جهت توسعه كشور است. به علاوه، توانايى رسيدن به وفاق در مورد

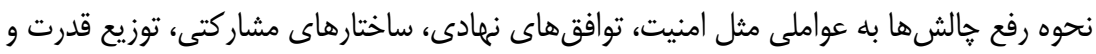
اختيارات و مسئوليتها دارد. بنابراين، نيل به توسعه پايدار يك وظيفه ضمنى در تغيير شكل شيوه

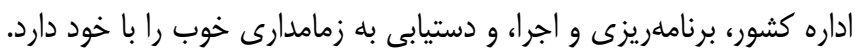

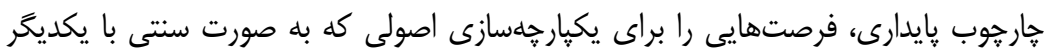
ناساز كار هستند، مانند عدالت بينسلى، حفاظت محيطزيست، و اثربخشى اقتصادى مهيا مى كند

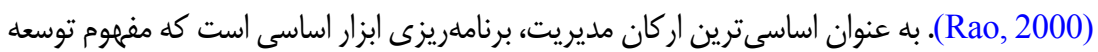

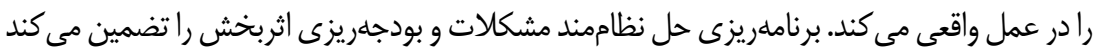
(Hrebik et al., 2006) كمك به يافتن ارتباط بهينهاى ميان تمام ابعاد توسعه و برآوردن كليه اصول بايدارى مانند جامعنحَىى (Kirkpatrick, 2001; Stoddart, 2011; Dernbach, 2003; Redclift, 2002) اقتضايى (UN, 2001)، ديدكاه سيستمى (Stillman, 2009; Pearce et al., 1987; Redclift, 2002)،

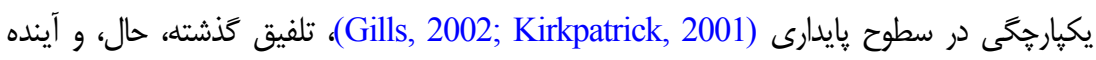

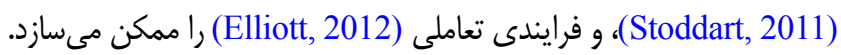
با وجود اركانهاى متعدد نظير معاونت برنامهريزى، معاونت مهندسى، يزوهش و فناورى، و

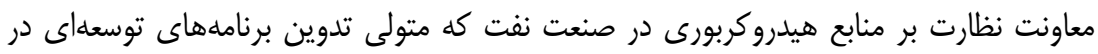
حوزه نفت و كاز هستند، و همجنين با وجود الزامهاى بينالمللى و ملّى، رويكرد توسعه هايدار بله عنوان محور تدوين برنامههاى توسعلاى مورد توجه قرار نمى گيرد. علت مىتواند ناشى از مفهون

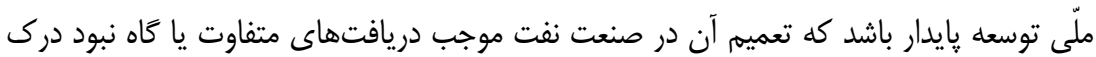

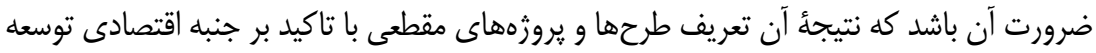

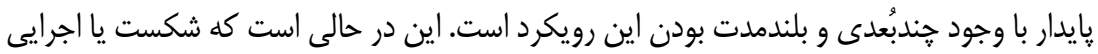
نشدن برنامههاى توسعاى عالاوه بر صرف هزينههاى كلان (هزينه سرمايه انسانى، سرمايه

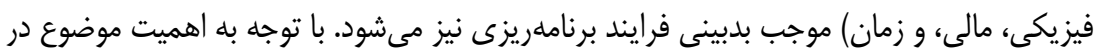

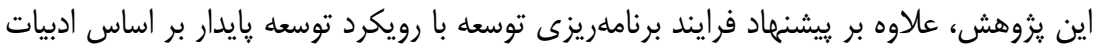

1. Good Governance 
موضوع و نظر متخصصان و خبر كان مربوطه در قالب فرايندهاى اصلى و فرعى، نتايج حاصل از از راز

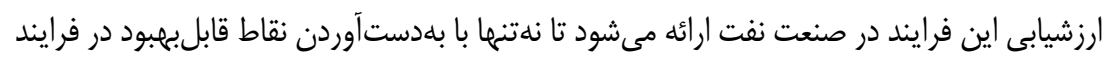

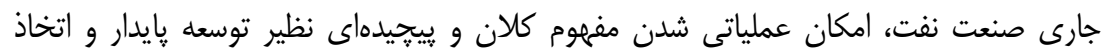

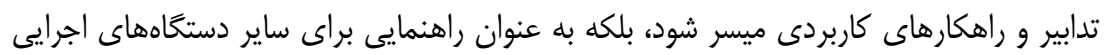
به منظور ارزشيابى اين فرايند مورد استفاده قرار كيرد.

مبانى نظرى يزووهش

توسعه بايدار، بر اساس كزارش كميسيون برانتلند بر مبناى ارتباط دادن مباحث توسعه اقتصادى

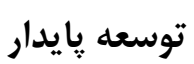

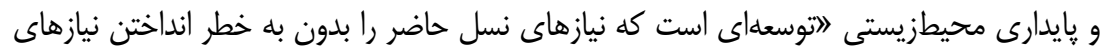

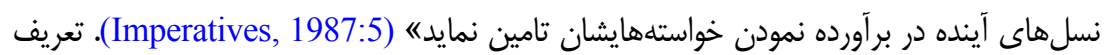

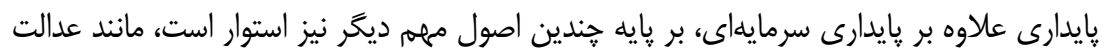

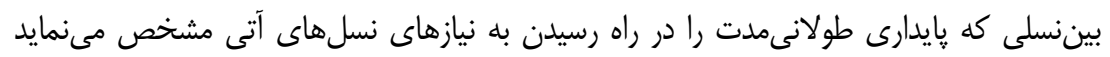

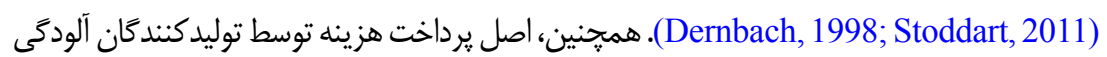

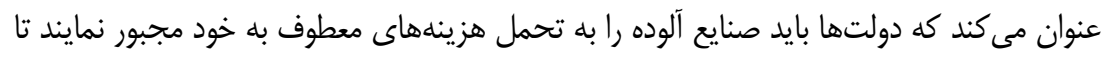

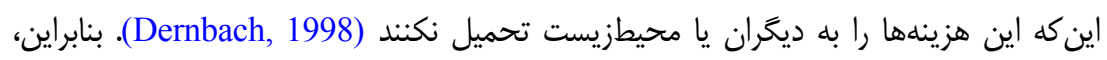

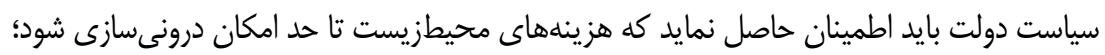

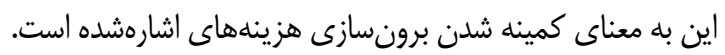

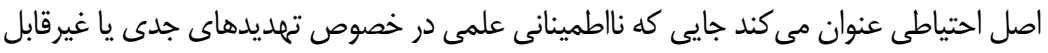

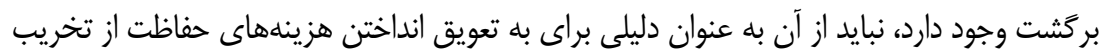

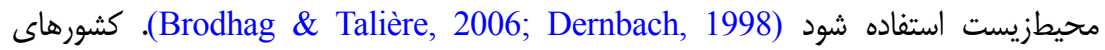

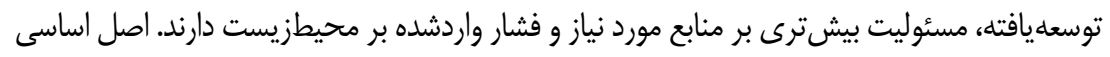

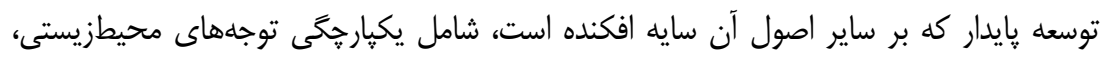

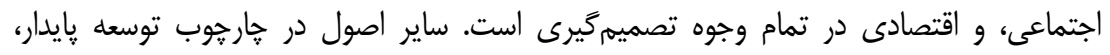

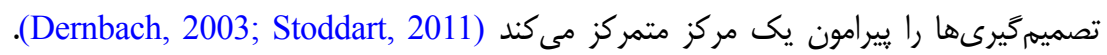

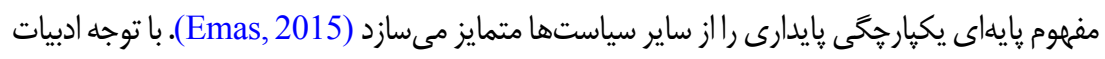

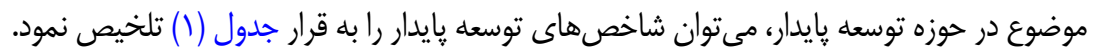


جدول 1: ابعاد و مولفههاى توسعه پֶايدار

\begin{tabular}{|c|c|}
\hline منابع & ابعاد و مولفه هاى تو \\
\hline $\begin{array}{l}\text { (Kirkpatrick, 2001; } \\
\text { Redclift, 2002; } \\
\text { Dernbach, 2003; } \\
\text { Stoddart, 2011) }\end{array}$ & 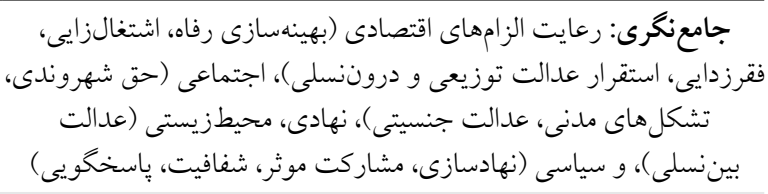 \\
\hline (UN, 2001) & اقتضايى: اهداف توسعه پِآيدار بايد در هر كشورى بهطور عملياتى و \\
\hline $\begin{array}{l}\text { Redclift, 2002; Pearce et al., } \\
\text { 1987; Stillman, 2009) }\end{array}$ & ديدگاه سيستمى: وابستكى متقابل ميان زندگى انسان و سيستمهاى، \\
\hline \multicolumn{2}{|c|}{ 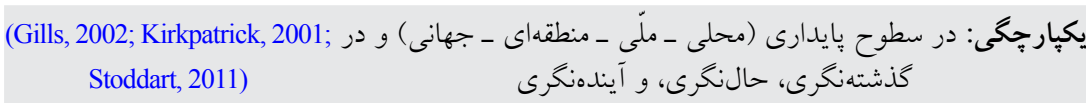 } \\
\hline (Elliott, 2012) & فرايندهاى تعاملى (براى افزايش سازگارى و تعادل) \\
\hline
\end{tabular}

\section{مديريت توسعه يايدار}

دست كم از دو راه مىتوان بين مديريت دولتى و توسعه يايدار يِيوند ايجاد كرد. اين حلقه يِيوند را مديريت توسعه پايدار' مىناميم. در معناى نخست، مديريت توسعه پايدار مى متواند به معناى اداره

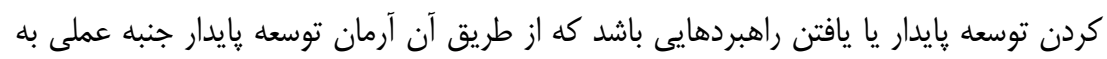

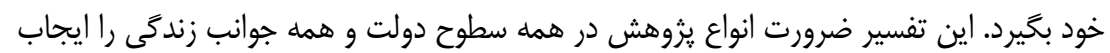
مى كند. اخر قرار باشد ايدهاى، رفتارها و اولويتهاى ما را تغيير دهد، نياز به برنامههايى داريم كه بتواند در تبديل آن ايده به واقعيت به ما كمك كند. در معناى دوم، مىتوانيهم مديريت توسعه يايدار را به عنوان حوزهاى فرعى تصور كنيه كه به يايدارى توسعه مديريت توجه دارد. در اين زمينه، نياز به يزوهش هايى درباره محيط متغير مديريت دولتى و راهبرد مورد نياز براى تطبيق يبدا كردن مديران دولتى و متخصصان مربوط به اين تغييرهاست. توسعه يايدار ديدمان جديدى در حوزه برويه

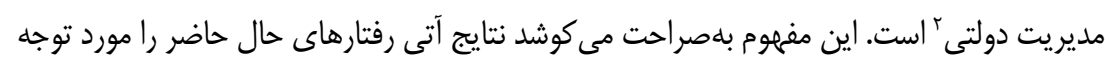

قرار دهد (Bartle \& Leunenberger, 2006; Rao, 2000). توسعه و نقشها و فعاليتهاى مديريتى دولت را مىتوان در ينج حوزه برناملريزى، سازماندهى،

1. Sustainable Development Administration (S.D.A)

2. Public Administration 
كنترل، هماهنكى، و هدايت تقسيهبندى نمود. عناصر اصلى خطمشى گذارى دولت در توسعه بايدار

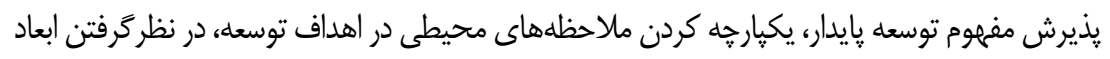

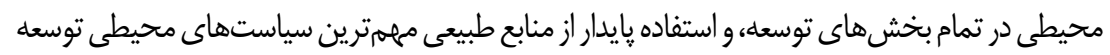

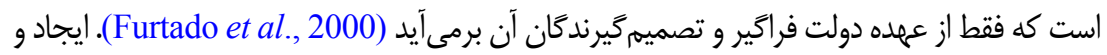

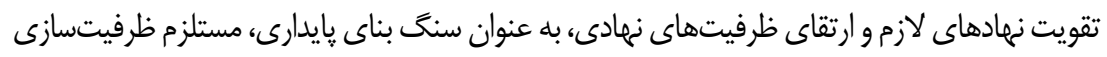

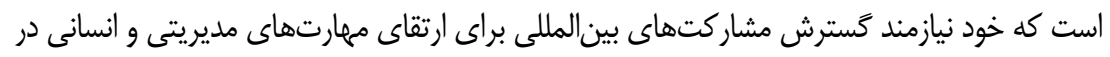

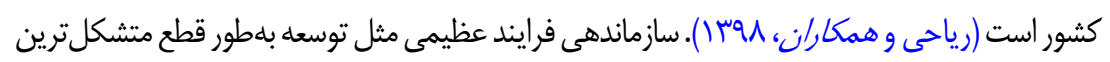

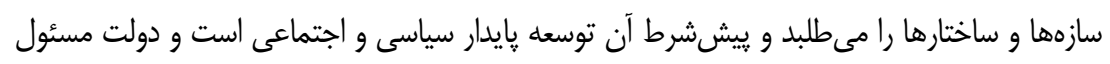

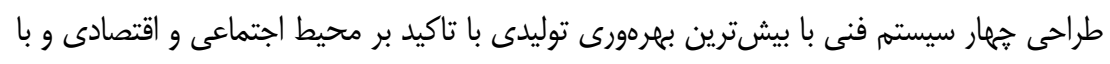

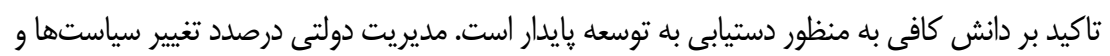

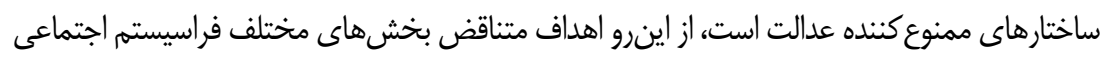
توسعه ايجاب مى كند كه عامل مافوق بر كل سيستم جامعا، نظارت، كنترل و مراقبت دائم داشته باشد.

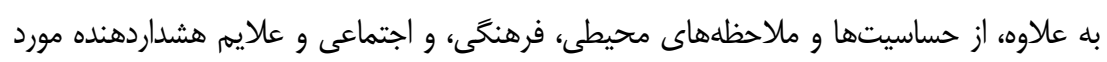

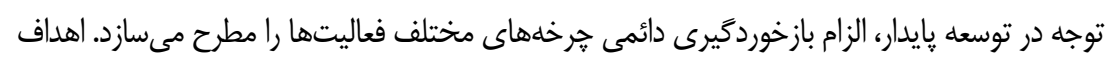

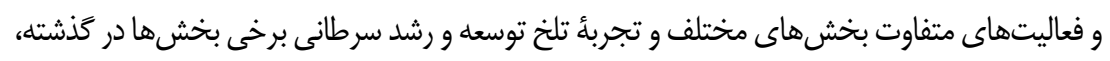

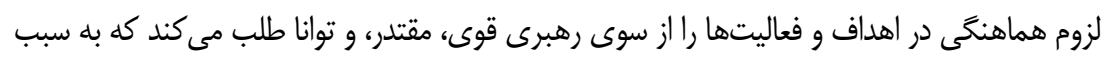

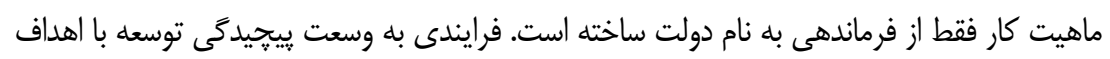

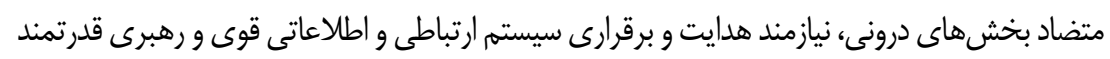
است كه فقط دولتها از عهده آن برمى آيند (Hughes, 2012).

\section{مدلهاى فر ايندى برناملريزى توسعه}

برنامهريزى ابزار اساسى است كه مفهوم توسعه يايدار را در عمل واقعى مى كند. برنامهريزى حل

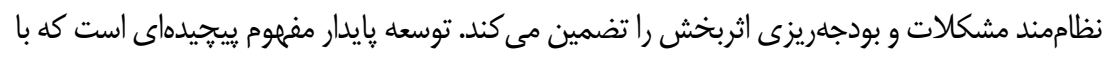

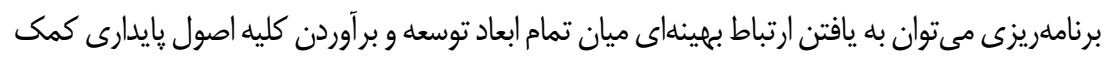

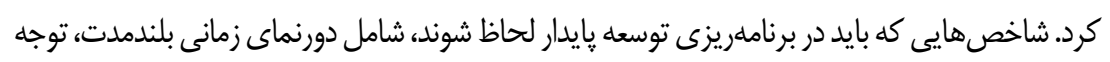

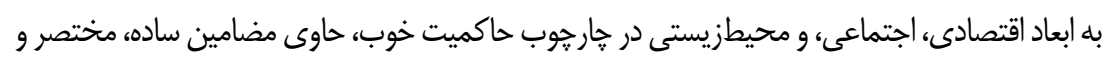

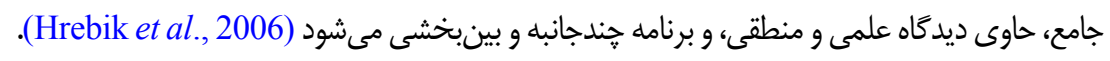


1. فرايند برنامهريزى بر اساس رويهها، روشها، و فنون بيشنهادى بخش هميارى فنى براى توسعه سازمان ملل

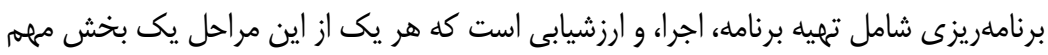
از فرايند برنامهريزى است. هر يك از اين سه مرحله روابط متقابلى با يكديكر دارند و در فعاليتها و مسئوليتهايى كه در مراحل مختلف هست، تداخل و هميوشانى فراوانى ييش مى مئي آيد. فرايند

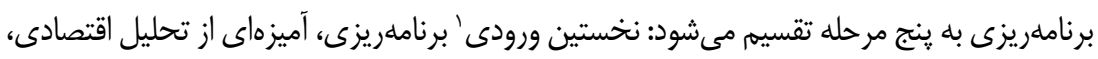

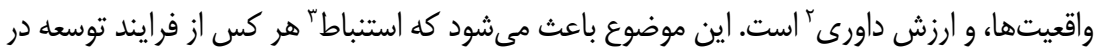

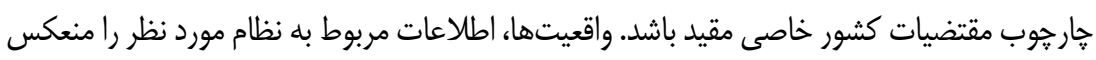

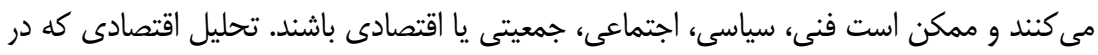

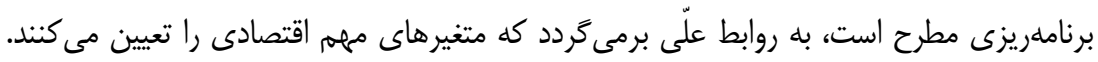

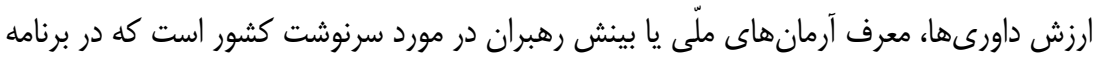
دخالت داده مىشود. واقعيتها و تحليل اقتصادى در حيطه وظايف كارشناسان

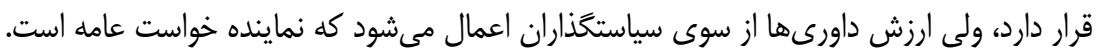

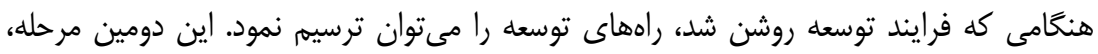

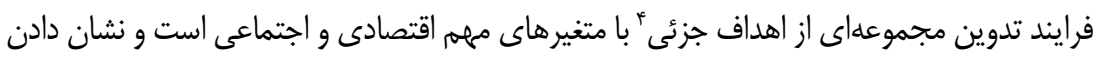

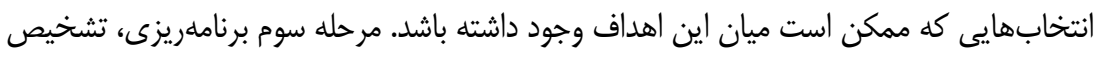
و تعيين \}= استراتزى

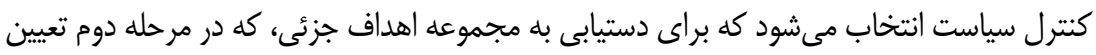

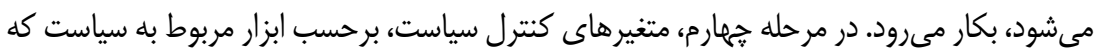

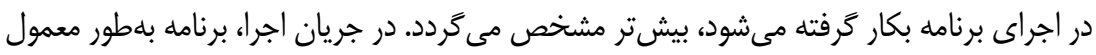

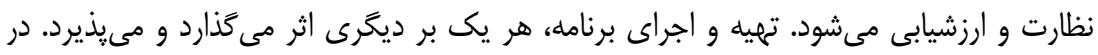

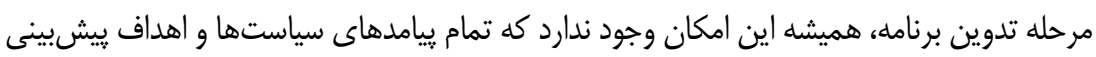

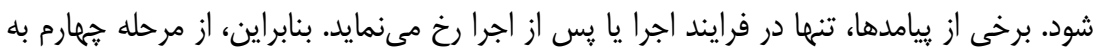

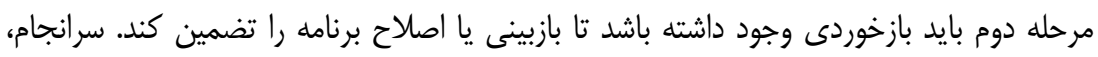

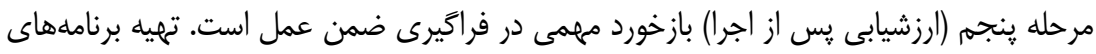

1. Input

2. Value Judgment

3. Understanding

4. Targets 
بعدى تا حد زيادى به تجربه و نتيجهاى كه از فرايند تهييه و اجراى برنامههاى ييشين بهدست مى آيد،

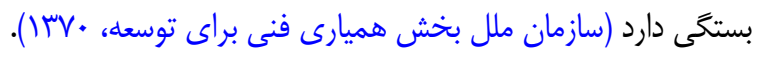

r. فرايند برنامهريزى توسعه بر اساس دستورالعمل برنامهريزى و ارزشيابى توسعه

"ايدار جمهورى جكى

اين فرايند در قالب ينج مرحله كلى است (Hrebik et al., 2006). در مرحله آغازين اقدام

به تعريف اهداف كلى و اهداف كمّى، تصميمَيرى در خصوص حوزه اختيارات، تعيين روشهاى

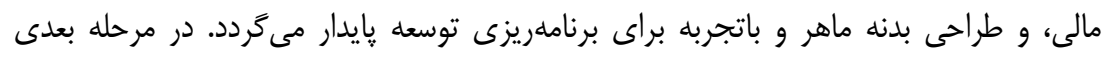

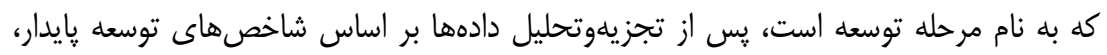

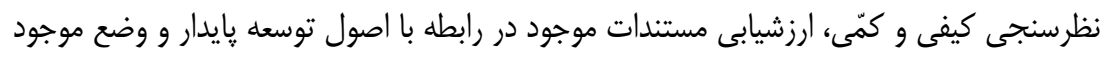

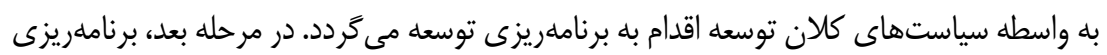

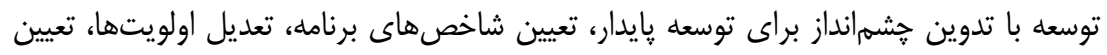

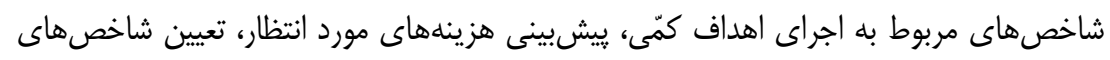

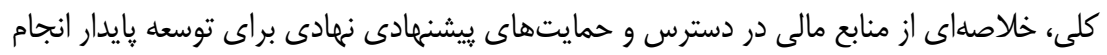

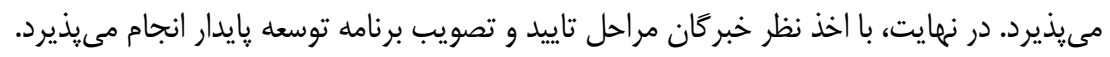

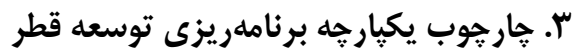

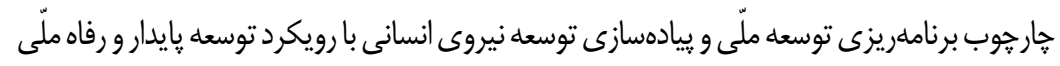

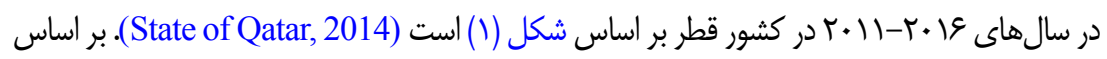

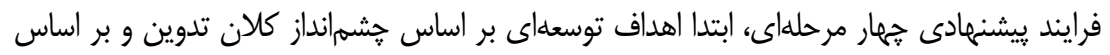

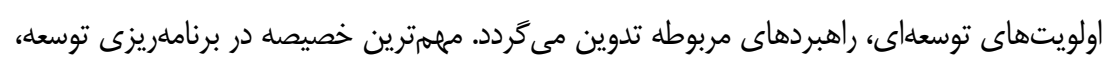

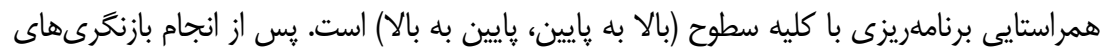

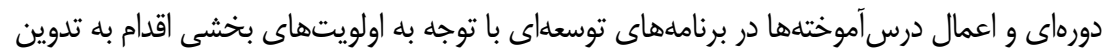

$$
\text { راهبردهاى بخشى مى گردد. }
$$

ع. فرايند بيشنهادى برنامهريزى، كنترل، و ارزشيابى توسعه توسط UNDP'

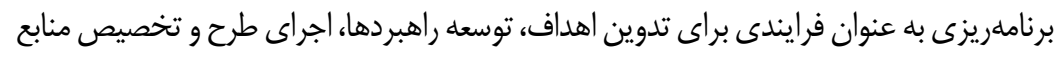

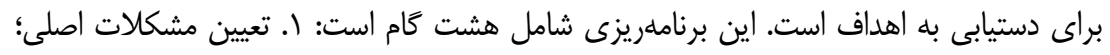

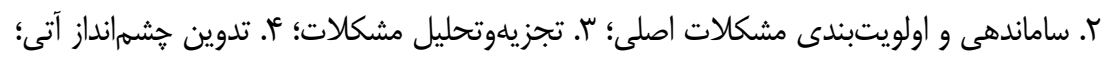

1. United Nations Development Programme

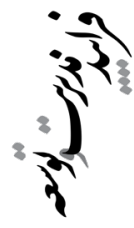

2
2
2
2
3
3
5
0
3
3
0
3
3
3
2
2 
ه. تهيه ييشنويس نقشه نتايج، كه در آن ذىنفعان اقدام به تدوين نتايج آنى مثبت و كليه نتايج بلندمدت

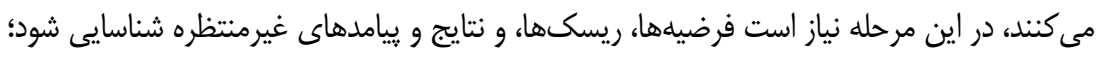

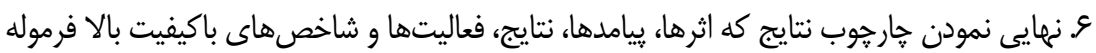
مىشوند؛ V. فرموله كردن شاخصهاى عملكرد؛ و يـ آماده شدن براى اجرا، كه تمام نيازمندىهاى

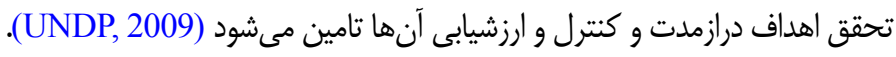

ه. فرايند برنامه ريزى بخشى در برنامه ششم توسعه فرايند برنامهريزى شامل هفت كام كلى است كه هر يكى به زيرفرايندهايى تقسيم مى بردود. در مرحله نخست، ساختار تدوين برنامه شكل مى

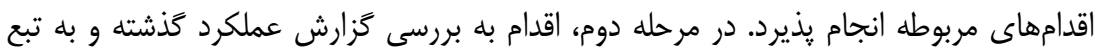
آن تبيين وضع موجود مى گردد. يس از يِيشبينى آينده و تبيين خطوط كلى توسعه به تامين و تجهيز منابع مورد نياز و تعيين الزامهاى تحقق اهداف و سياستها اقدام مىشود، جنانجه براى

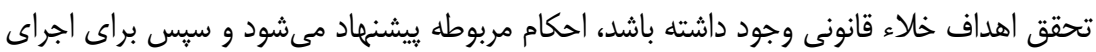
برنامههاى توسعهاى اقدام به اولويتگذارى و تهيه برنامههاى اجرايى براى موضوعهاى خاص

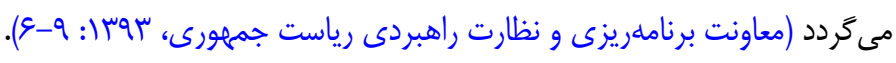

جدول r: مقايسه مدلهاى فرايندى در حوزه توسعه هِايدار

\begin{tabular}{|c|c|c|}
\hline رويكرد برنامهريزى & 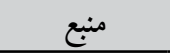 & 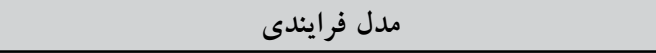 \\
\hline رويكرد توسعه يايدار & سازمان ملل & 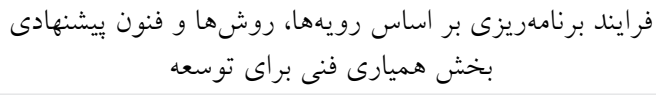 \\
\hline رويكرد توسعه يايدار & جمهورى جِى & فرايند برنامهريزى توسعه بر اساس دستورالعمل برنامهريزى و \\
\hline 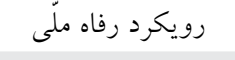 & 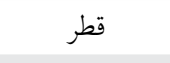 & جارجوب يكيارجه برنامهريزى توسعه \\
\hline رويكرد عملياتى & UNDP & فرايند يِيشنهادى برنامهريزى، كنترل، و ارزشيابى توسعه \\
\hline رويكرد اقتصادى & 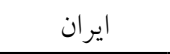 & فرايند برنامهريزى بخشى در برنامه ششم توسعه \\
\hline
\end{tabular}

با بررسى فرايندهاى برناملريزى موجود در ادبيات موضوع دو رويكرد متفاوت در برناملريزى

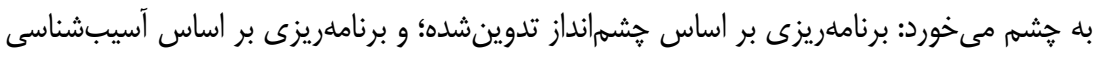
مشكلات و معضلات موجود در حوزه توسعه پايدار. در رويكرد يكم، كه مبناى برنامهريزى در ايران و

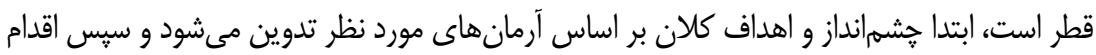

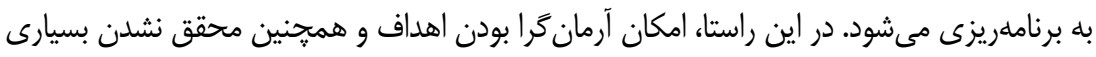


از اهداف از ييش تعيينشده وجود دارد. در صورتى كه در برنامه ييشنهادى UNDP، برنامهريزى

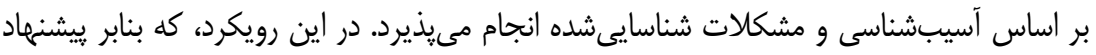
بNDP براى تضمين اهداف تعيينشده بايد ريسكهاى اجرايى شناسايى شوند، امكان تحقق اهداف

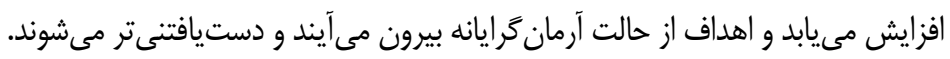

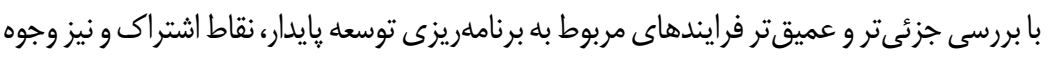

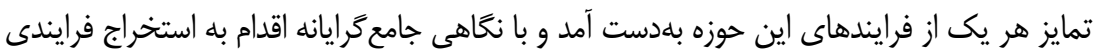

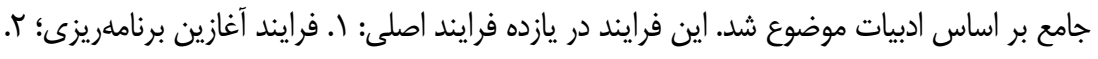

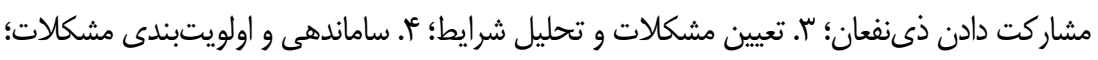

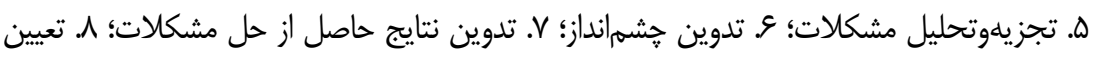

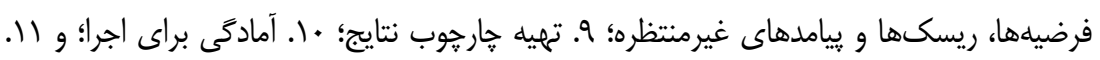

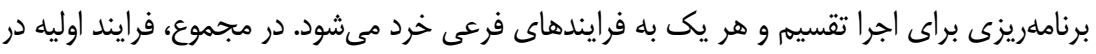

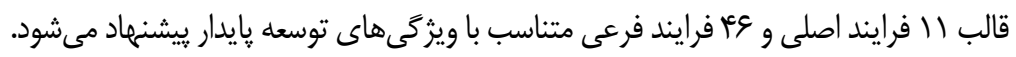

\section{ارزشيابى}

ارزشيابى كاربرد موثرى دارد و ارتقاى برنامه، ايجاد دانش، و پاسخكويى را حمايت مى كند.

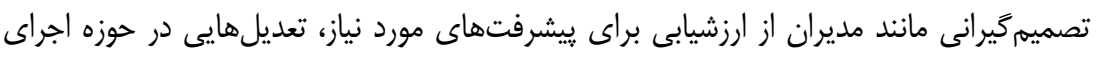

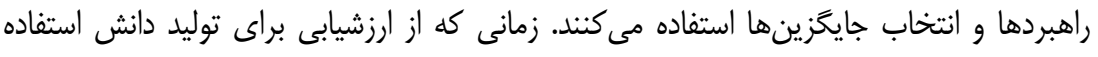

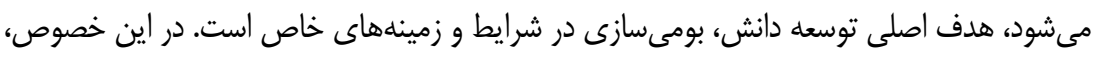

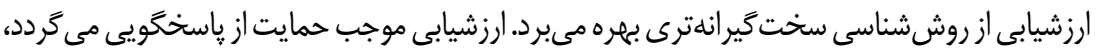

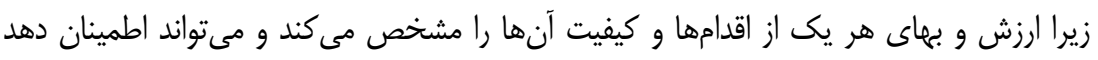

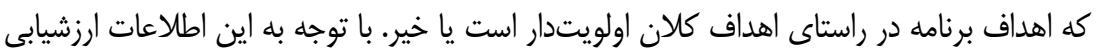

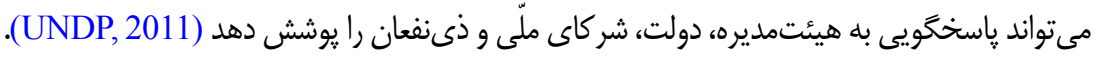

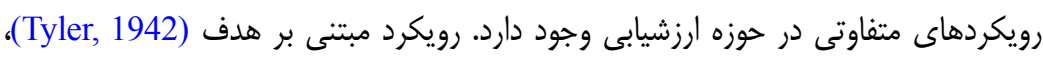

بر ميزان تحقق اهداف برنامه تمركز دارد. رويكرد مبتنى بر مديريت (Stufflebeam, 1971)،

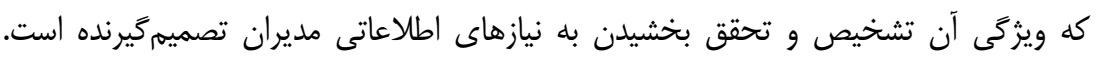

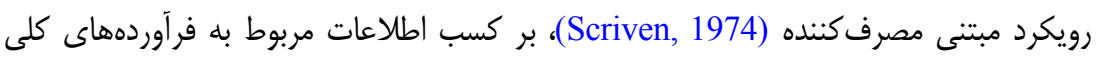

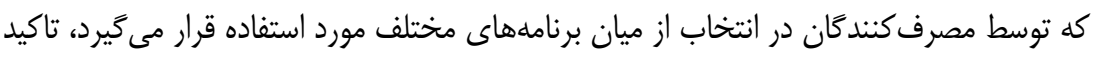
مى كند. رويكرد مبتنى بر نظر متخصصان (Worthen \& Sanders, 1987)، بر كاربرد مستقيم 
نظر متخصصان در قضاوت درباره كيفيت فعاليتها تمركز دارد، و رويكرد مبتنى بر اختلاف نظر

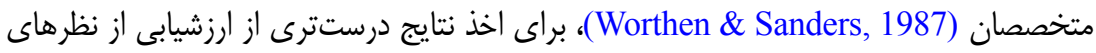

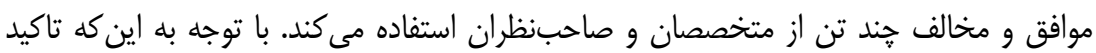
اصلى رويكرد مبتنى بر نظر متخصصان بر كاربرد مستقيم نظر متخصصان در قضاوت درباره كيفيت

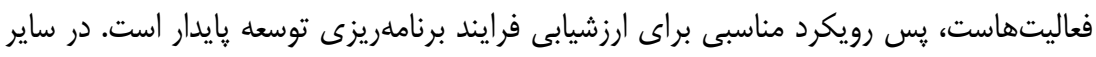
رويكردها، هدف يا ارزشيابى ميزان تحقق اهداف است (رويكرد مبتنى بر هدف) يا دروندادها،

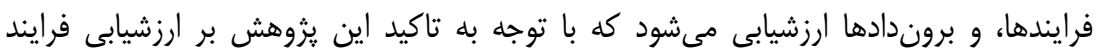

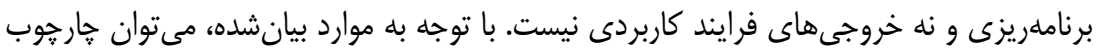

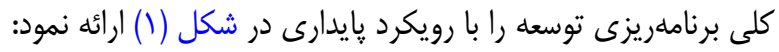

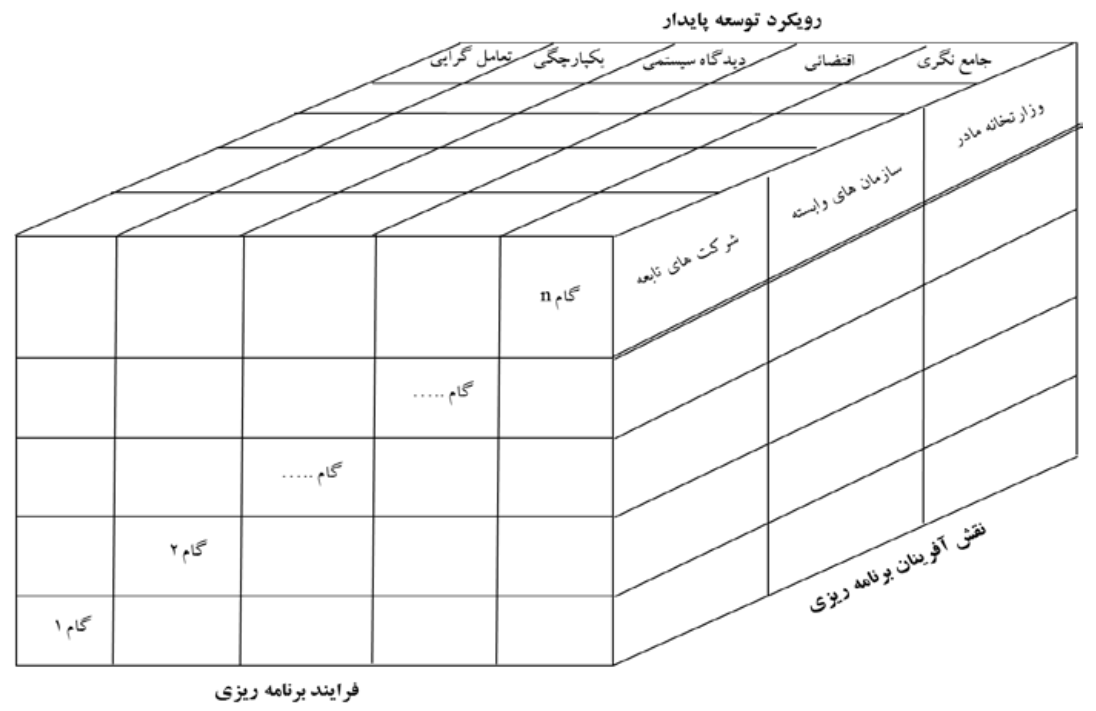

شكل 1: جارجوب مفهومى فرايند برنامهريزى در بخش دولتى با رويكرد توسعه پِايدار

بر اساس خار خوب كلى ارائهشده برنامهريزى توسعه با رويكرد پايدارى در بخش صنعت نفت به سه برسش ياسخ داده خواهد شد:

ا. كامهاى اصلى و فرعى برنامهريزى توسعه پايدار در صنعت نفت ايران كداماند؟

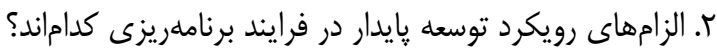

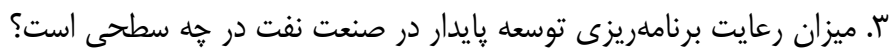




\section{روششناسى بزؤهش}

به دليل مفهوم ملّى توسعه بايدار، واحد تحليل اين يزوهش ملّى است و به جهت اهميت

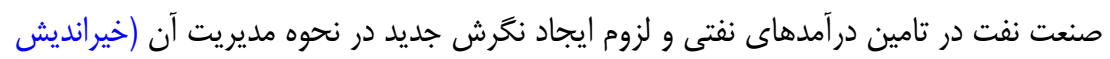

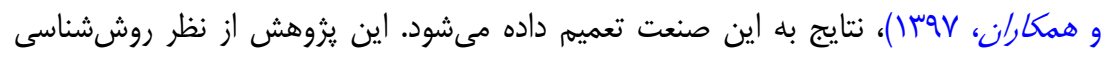

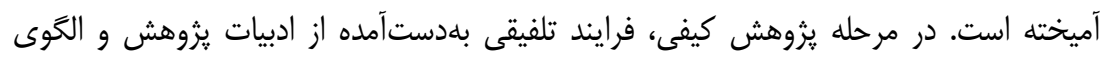

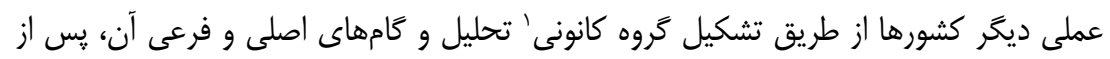

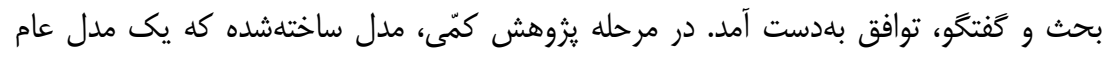

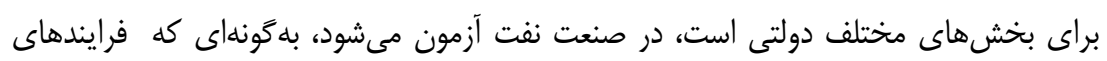

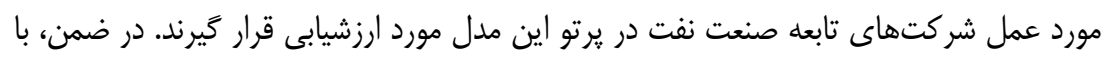

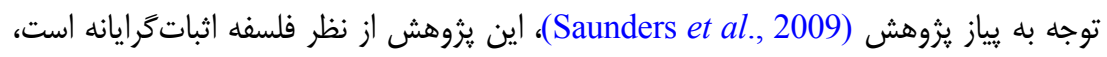

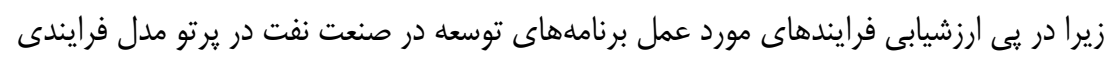

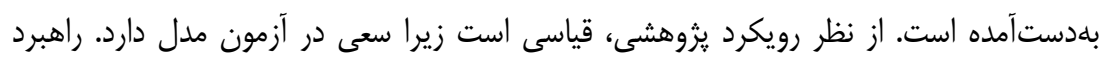

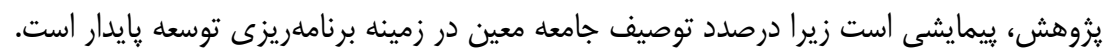

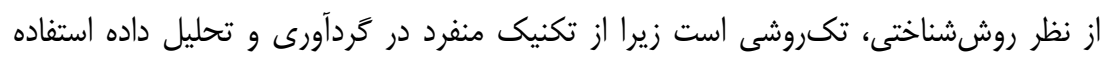

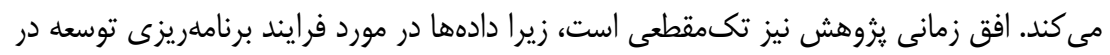

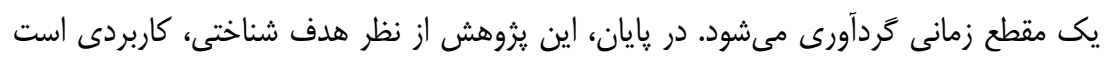

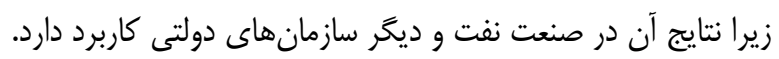

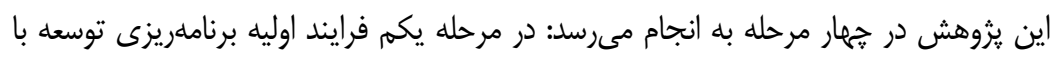

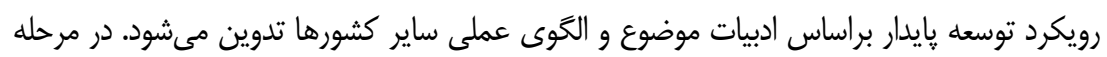

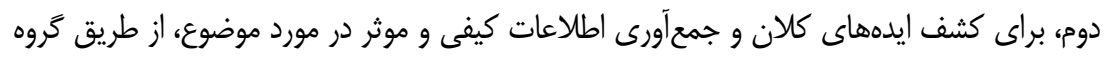

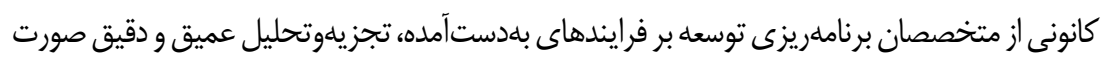

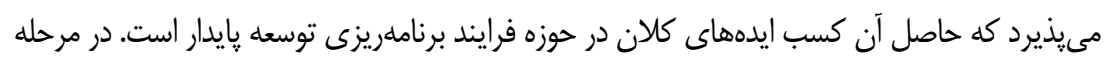

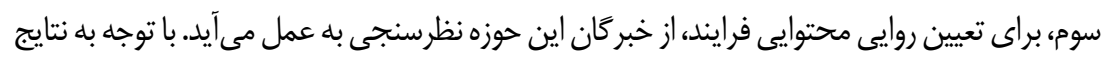

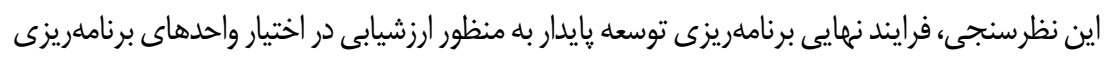

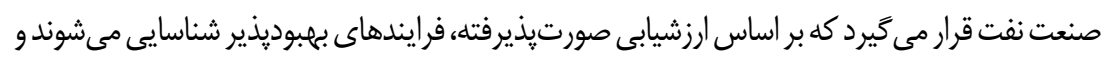

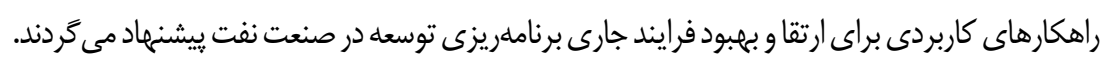

1. Focus Group 
كَروه كانونى: به منظور تاييد و اعتبارسنجى مدل فرايندى حاصل از بررسىهاى صورت گرفته،

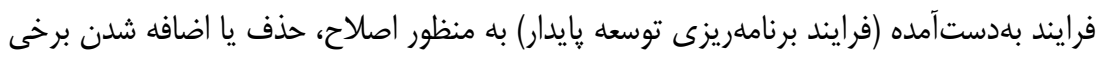

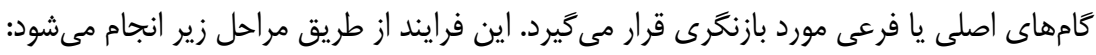

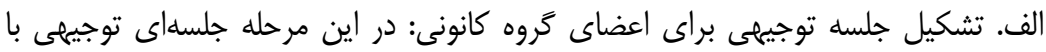

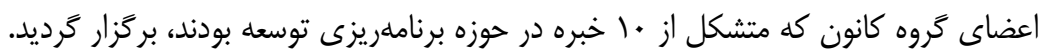

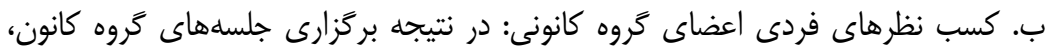
نظرهاى هر يك از اعضاى گروه كانونى اخذ كرديد.

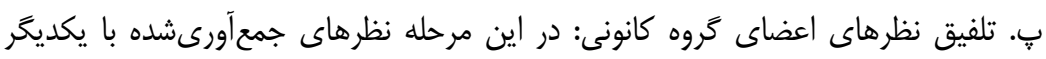

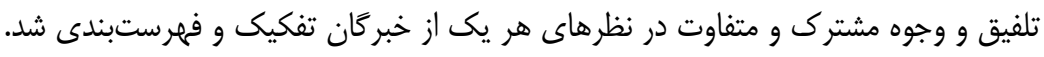

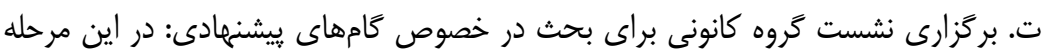

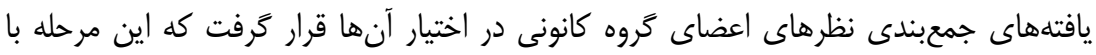
توصيف مدل فرايندى جديد همراه بود.

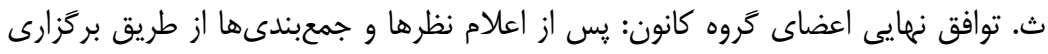

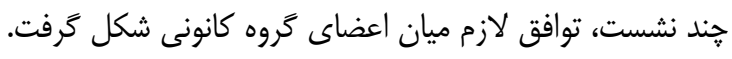

\begin{tabular}{|c|c|c|c|c|c|c|c|}
\hline \multicolumn{8}{|c|}{ جدول "ז: ويز كى هاى جمعيتشناختى كروه كانونى } \\
\hline \multicolumn{3}{|c|}{ تجربه (تعداد) } & \multicolumn{2}{|c|}{ جنس (تعداد) } & \multicolumn{3}{|c|}{ سن (تعداد) } \\
\hline$I Y-I V$ & $|\Lambda-r|$ & $r Y-r q$ & مرد اد & زن - ت ان & $y \cdot-k r$ & $k t-k V$ & $\langle\wedge-0|$ \\
\hline V & r & 1 & 4 & k & V & r & 1 \\
\hline
\end{tabular}

روايى محتوايیى: پِ از توافق نهايى اعضاى كَروه كانونى و جمعبندى نظرها، فرايند

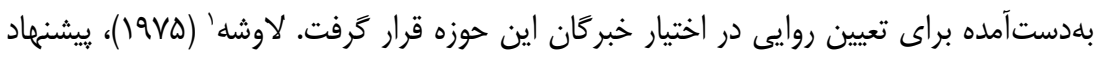

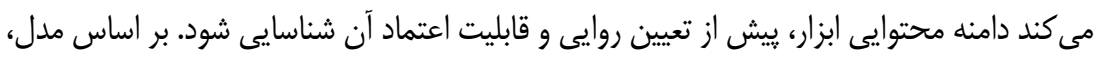

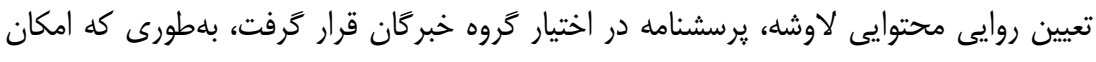

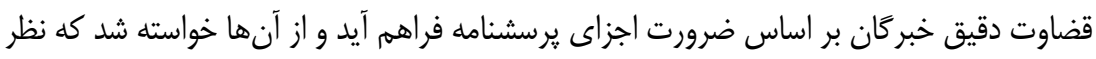

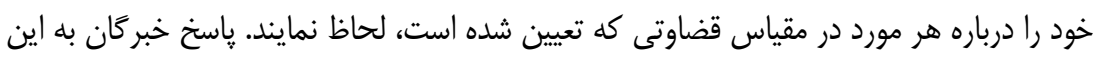




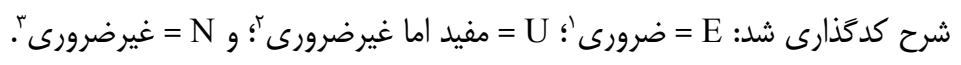

كروه خبركان متشكل از متخصصانى بود كه در حوزه محتوايى يرسشنامه فعاليت داشتند.

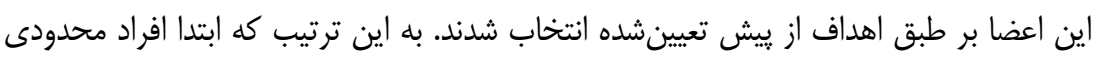
به عنوان سرگروه در حوزه دامنه محتوايى مطالعه انتخاب شدند و از اين افراد در شناسايى ساير

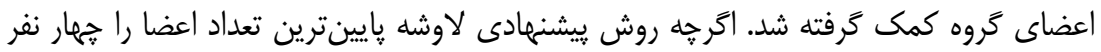

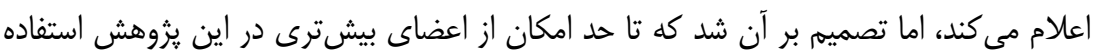
شود. اين تصميم ضمن غلبه بر محدوديتهاى آتى نظير انصراف افراد در شركت در مر مطالعه و برگشت نكردن يرسشنامه، باعث افزايش قابليت اطمينان نتايج مىشود. به دليل مشكلاتى مانند تعداد كم متخصصان در حوزه توسعه يايدار و خندتخصصى بودن دامنه محتوايى اين يزوهش

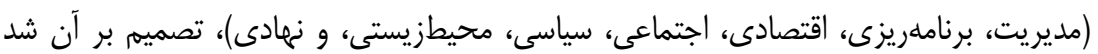
كه دست كم ها نفر در روند روايىسنجى اين يرسشنامه شركت كنند. تعداد • ب خبره در حوزههاى مديريت توسعه، برناملريزى اقتصادى، اجتماعى، سياسى، محيطزيستى، و نهادى شناسايى شدند

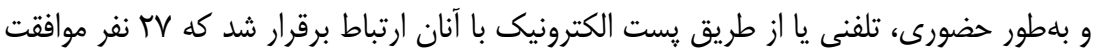

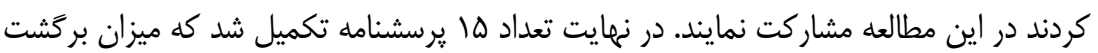

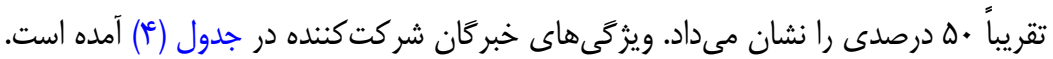

\begin{tabular}{|c|c|c|}
\hline \multicolumn{3}{|c|}{ جدول †+: تركيب و ويز كى اعضاى يانل } \\
\hline مدرى تحصيلى & ت تعداد & تخصص \\
\hline دكترى تخصصى & V & مديريت توسعه يايدار \\
\hline دكترى تخصصى & $r$ & برنامهريزى اقتصادى و اجتماعى \\
\hline دكترى تخصصى & r & مديريت دولتى \\
\hline دكترى تخصصى & 1 & مديريت محيطزيست \\
\hline
\end{tabular}

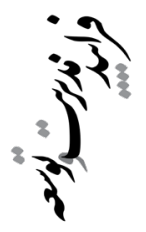

آراى خبر گان كه به گزينه E (ضرورى) تعلق گرفته است، از طريق نسبت روايى محتوايى كه از اين يس با اختصار CVR ناميده مىشود، كمّىسازى مىشود. فرمول ( () بدين منظور بكار مىرود: $\mathrm{CVR}=\frac{n e-\frac{n}{2}}{\frac{n}{2}}$

1. Essential

2. Useful But Not Essential

3. Not Necessary

4. Content Validity Ratio 


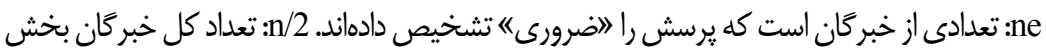

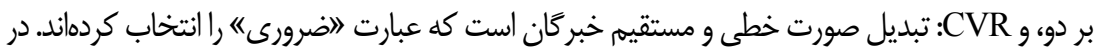

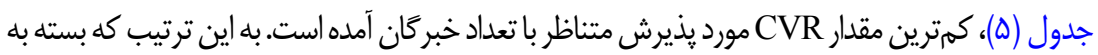

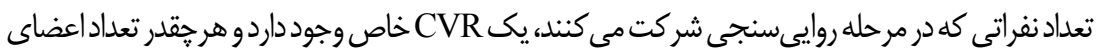

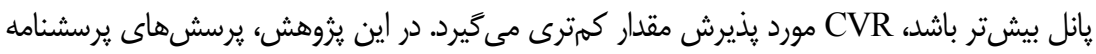

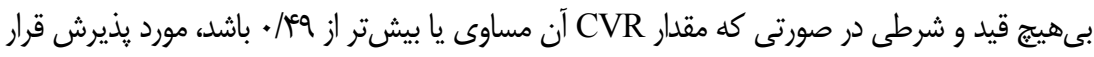

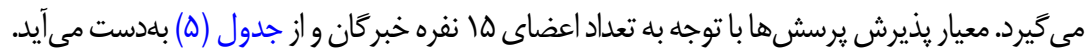

\section{جدول ه: كمترين مقادير CVR قابلقبول بر اي تعدادهاى متفاوت از خبر كان (Lawshe, 1975)}

\begin{tabular}{|c|c|}
\hline كمترين مقادير CVR قابل قبول & تعداد خبر گان \\
\hline$\cdot / 99$ & 0 \\
\hline.$/ 99$ & 4 \\
\hline$\cdot / 99$ & V \\
\hline - /VQ & $\wedge$ \\
\hline$\cdot / \mathrm{VA}$ & 9 \\
\hline . /GY & 1. \\
\hline$\cdot / 09$ & 11 \\
\hline$\cdot 109$ & $1 \pi$ \\
\hline$\cdot / \Delta Y$ & $1 r$ \\
\hline$\cdot / 01$ & 14 \\
\hline$\cdot / 4 q$ & 10 \\
\hline . MT & $r$. \\
\hline$\cdot / r V$ & rQ \\
\hline זת/• & $r$. \\
\hline | & ro \\
\hline$\cdot / \pi q$ & $r$. \\
\hline
\end{tabular}

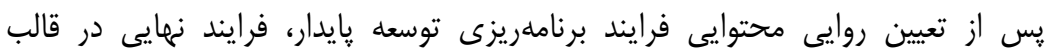

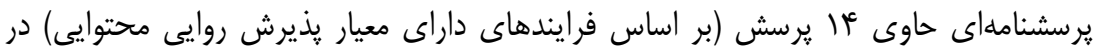

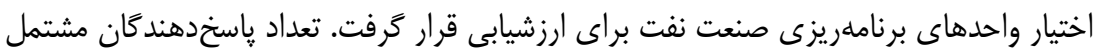




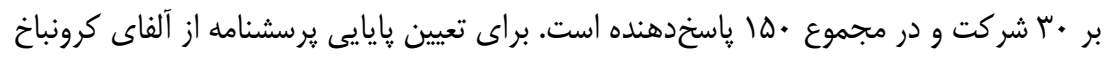
استفاده مىشود.

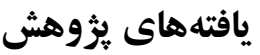

توافق صورت كرفته ميان اعضاى كروه كانونى در خصوص گامهاى اصلى و فرعى فرايند

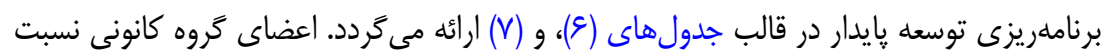

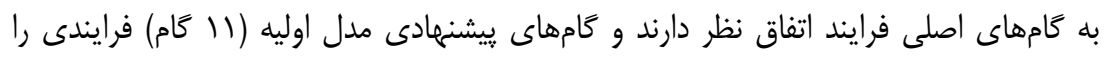
تاييد مى كنند.

جدول \&: توافق كروه كانونى در مورد كامهاى اصلى فرايند برنامهريزى توسعه يايدار

\begin{tabular}{|c|c|c|}
\hline 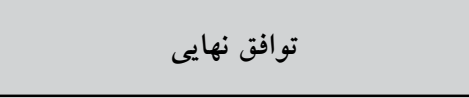 & بيشنهاد اوليه & فرايند \\
\hline فرايند آغازين برنامهريزى & فرايند آغازين برنامهريزى & 1 \\
\hline فرايند مشاركت دادن ذىنفعان & فرايند مشاركت دادن ذىنفعان & r \\
\hline فرايند تعيين مشكلات و تحليل شرايط & فرايند تعيين مشكلات و تحليل شرايط & r \\
\hline فرايند ساماندهى و اولويتبندى مشكلات & فرايند ساماندهى و اولويتبندى مشكلات & 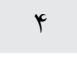 \\
\hline فرايند تجزيهو تحليل مشكلات & فرايند تجزيهو تحليل مشكلات & $\Delta$ \\
\hline فرايند تدوين جشم|نداز & فرايند تدوين جشم|نداز & 4 \\
\hline فرايند تدوين نتايج حاصل از حل مشكلات & فرايند تدوين نتايج حاصل از حل مشكلات & V \\
\hline فر ايند تعيين فرضيه ها، ريسكاى غيرمان و & فرايند تعيين فرضيهها، ريسكهام غيرما و & $\wedge$ \\
\hline فرايند تهيه جارجوب نتايج & فرايند تهيه جارجوب نتايج & 9 \\
\hline فرايند آمادكى براى اجرا & فرايند آمادكى براى اجرا & $1 \cdot$ \\
\hline فرايند برنامهريزى براى اجرا & فرايند برنامهريزى براى اجرا & 11 \\
\hline
\end{tabular}

कर्क

2
2
0
2
2
3
3
5
5
1
3
3
0
2
3
3
3
2
2

توافقهاى صورتخرفته بر كامهاى فرعى به شرح جدول (V) است. 


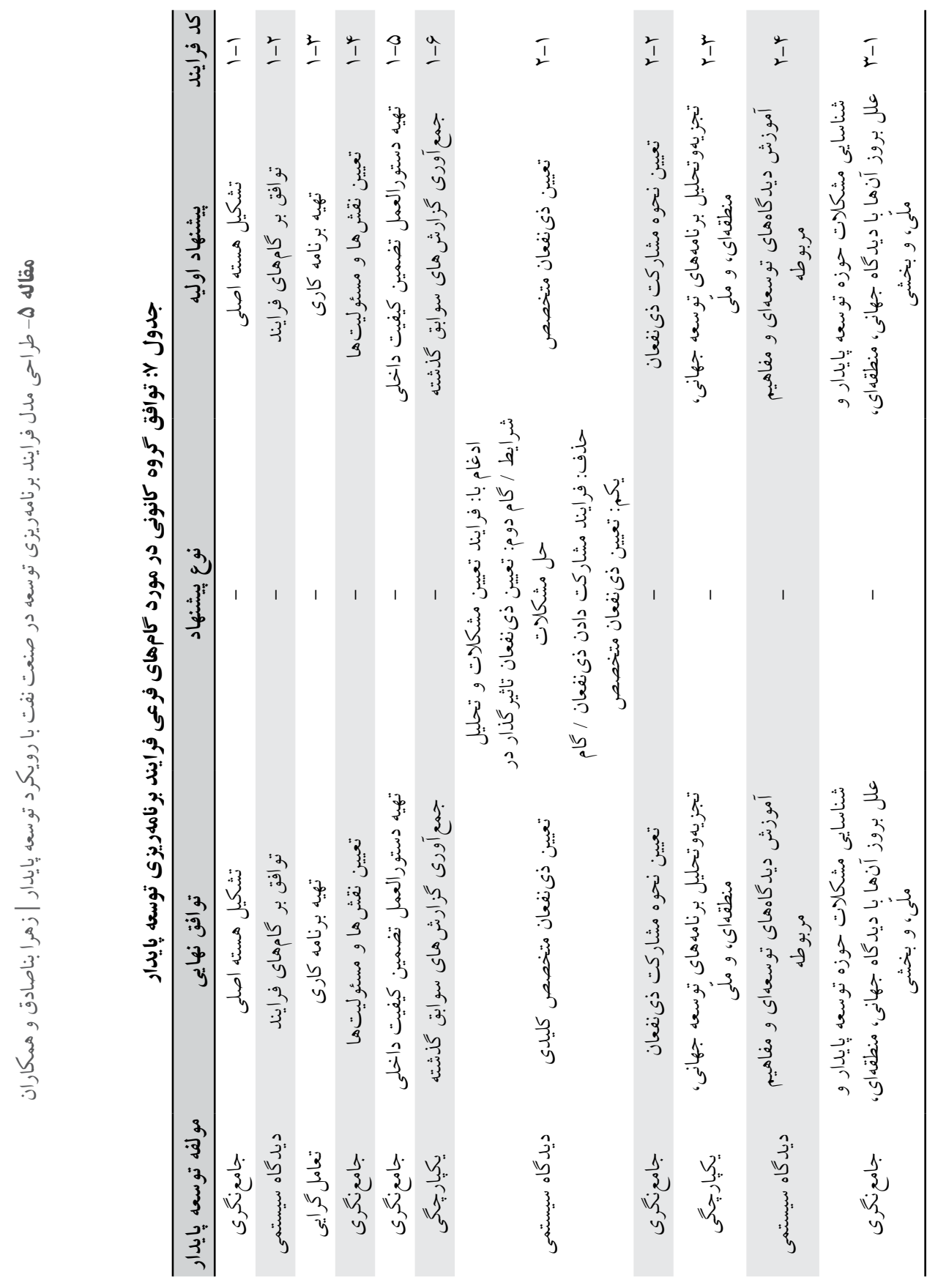




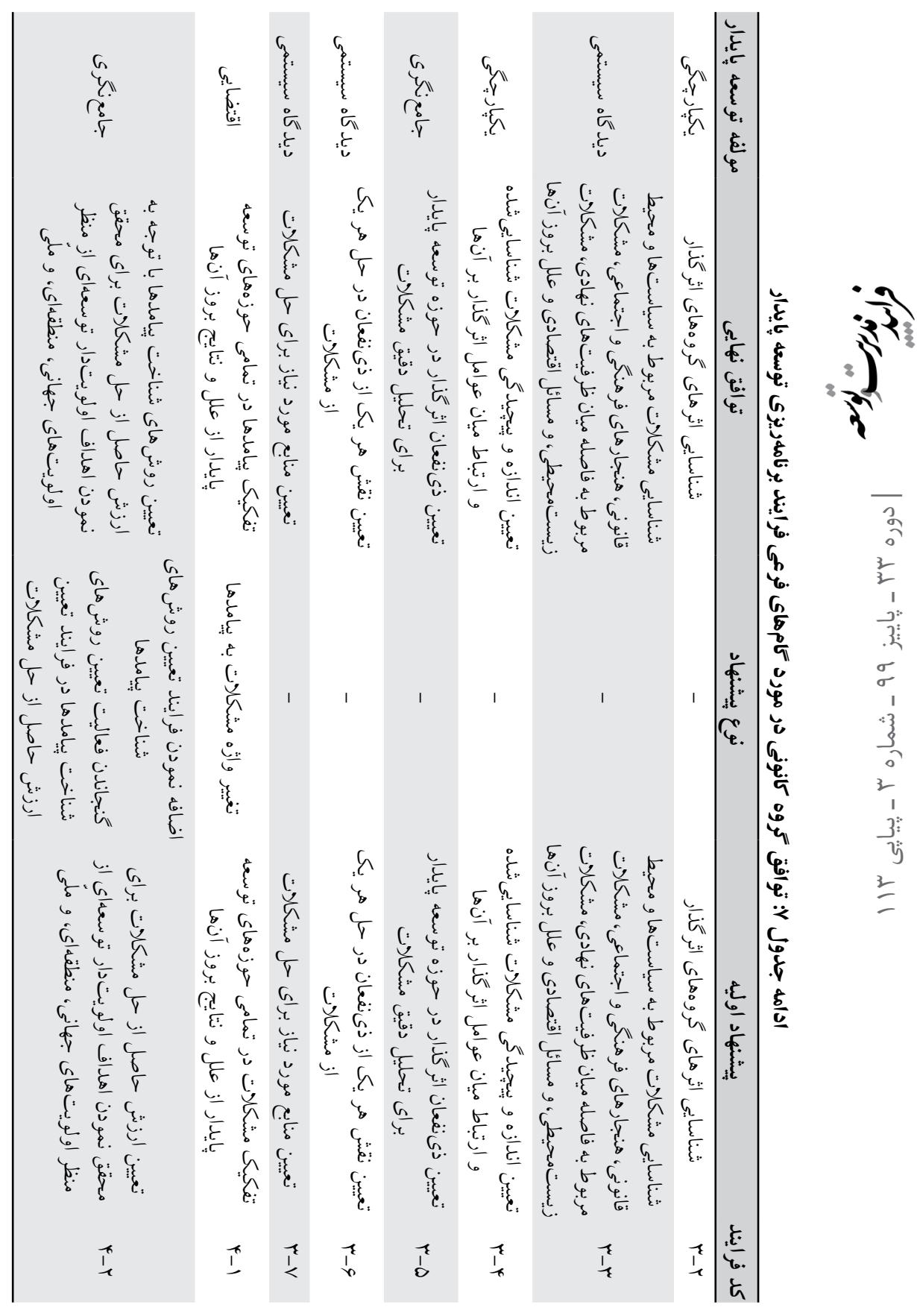




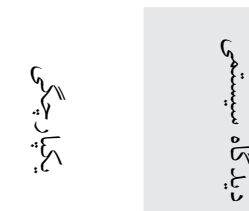

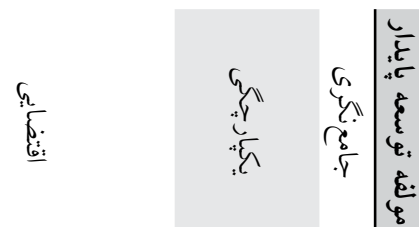

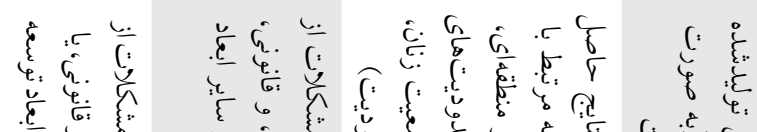

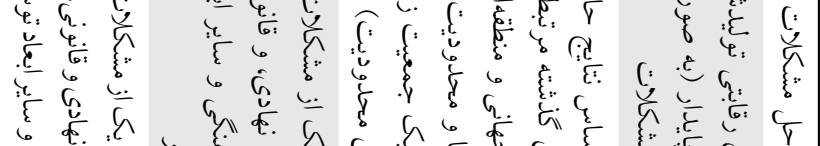

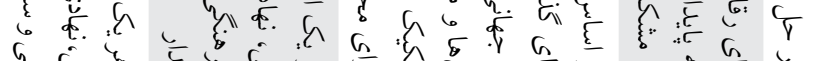

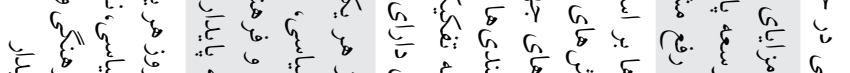

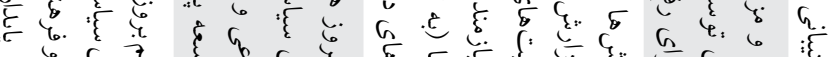

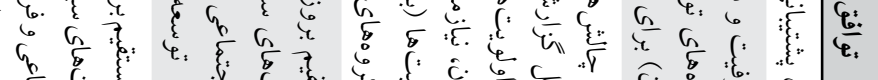

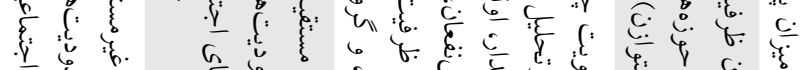

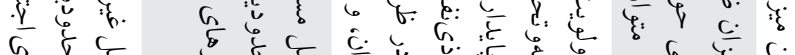

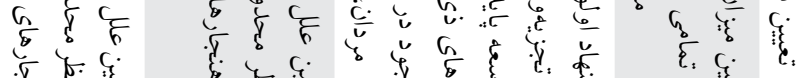

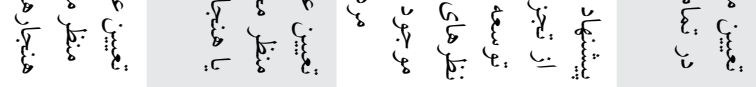

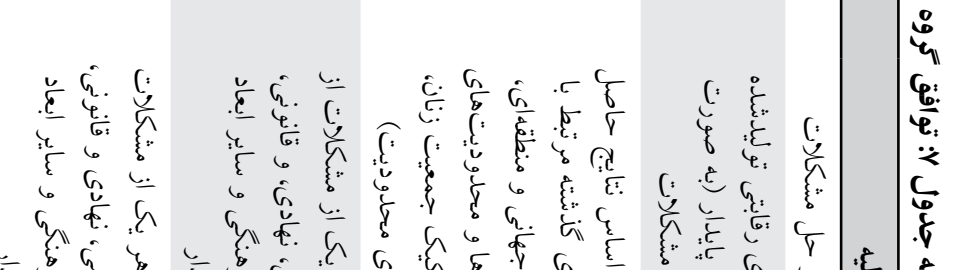

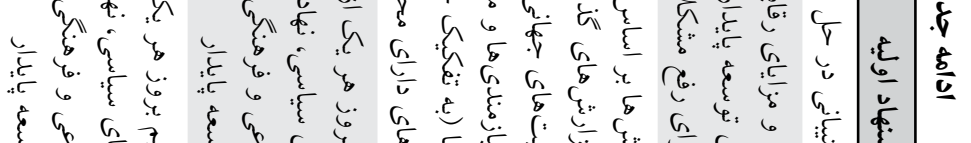

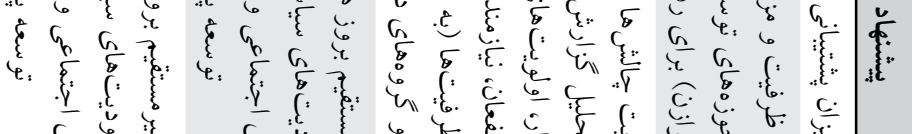

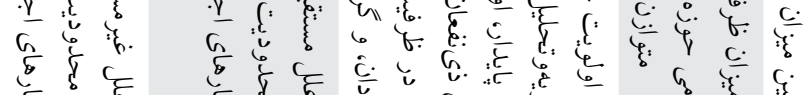

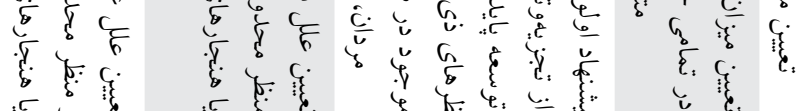

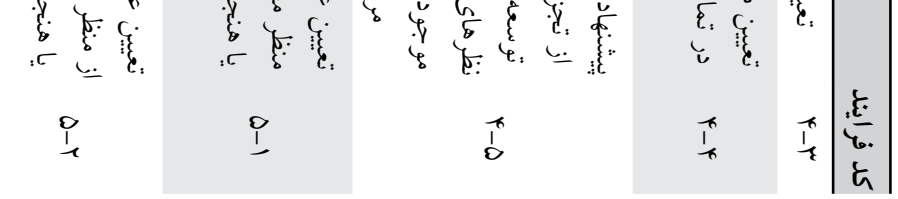




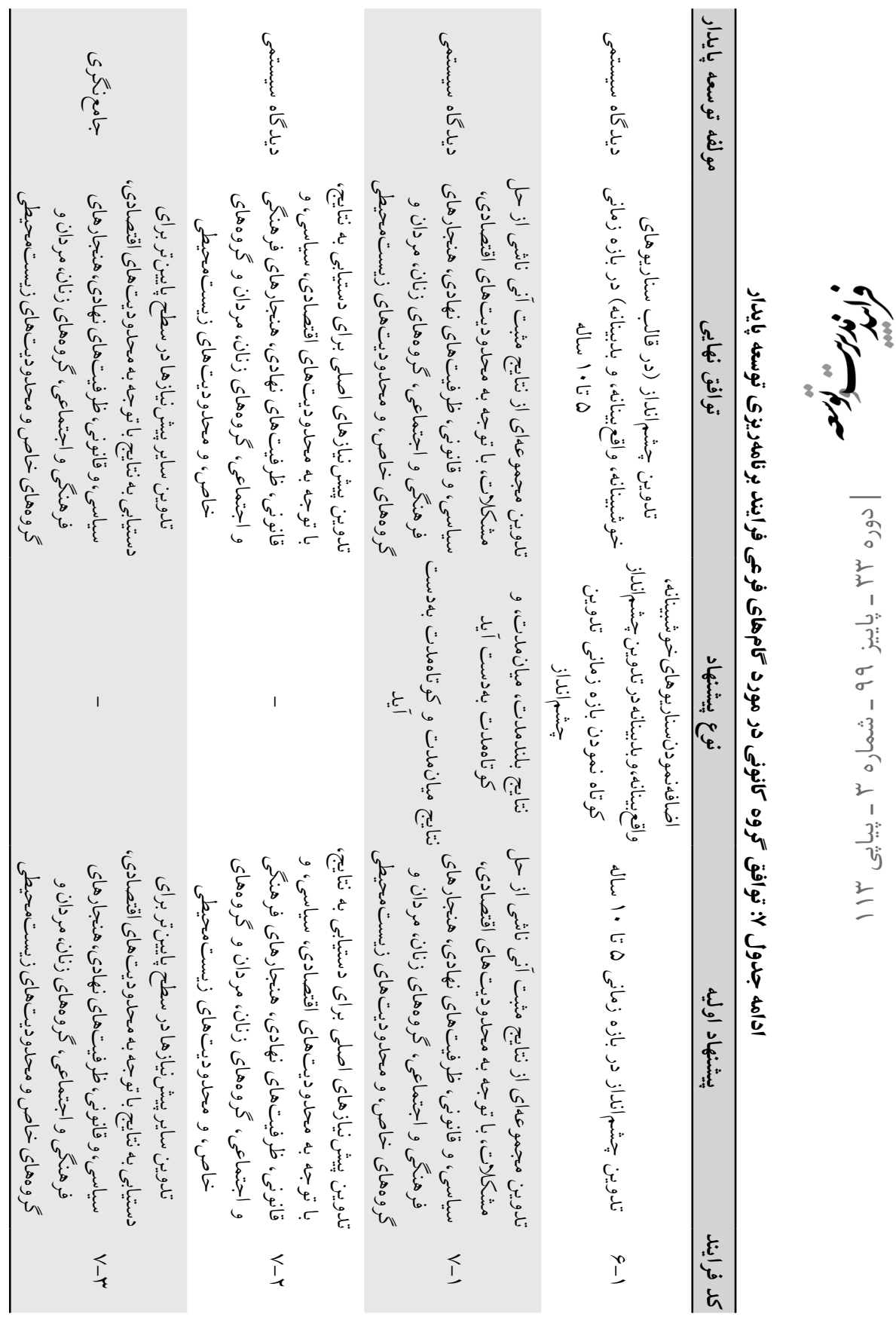




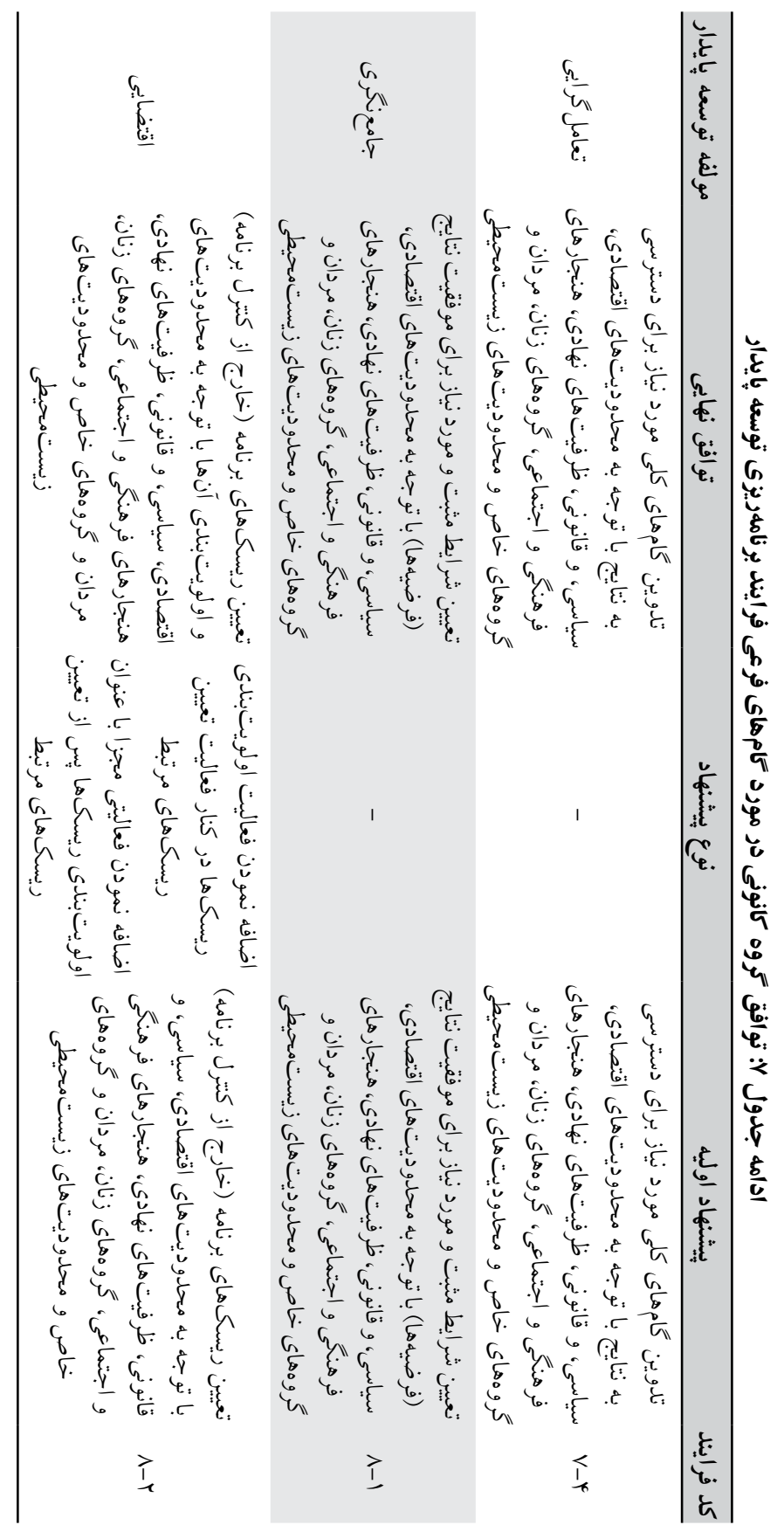




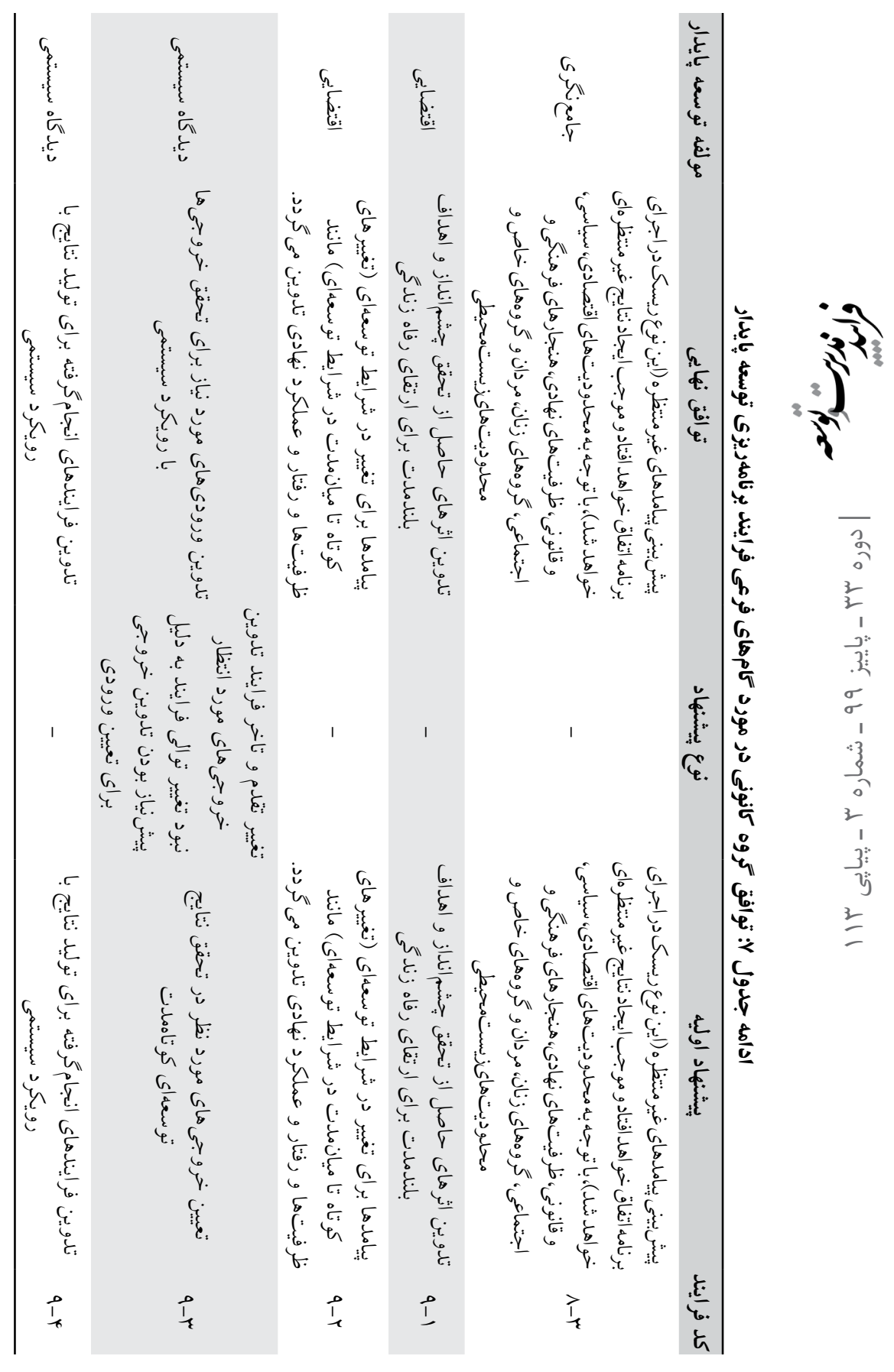




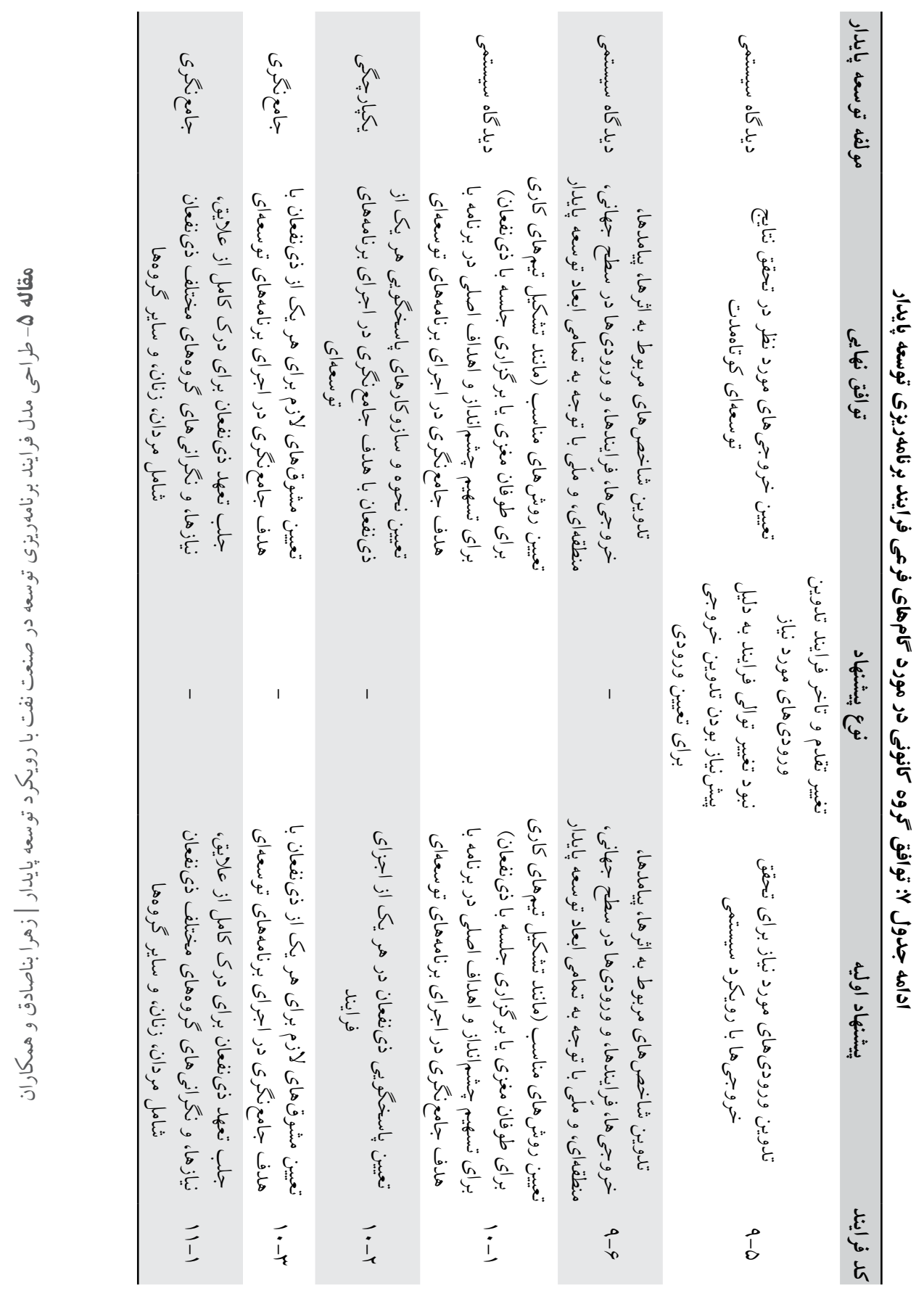



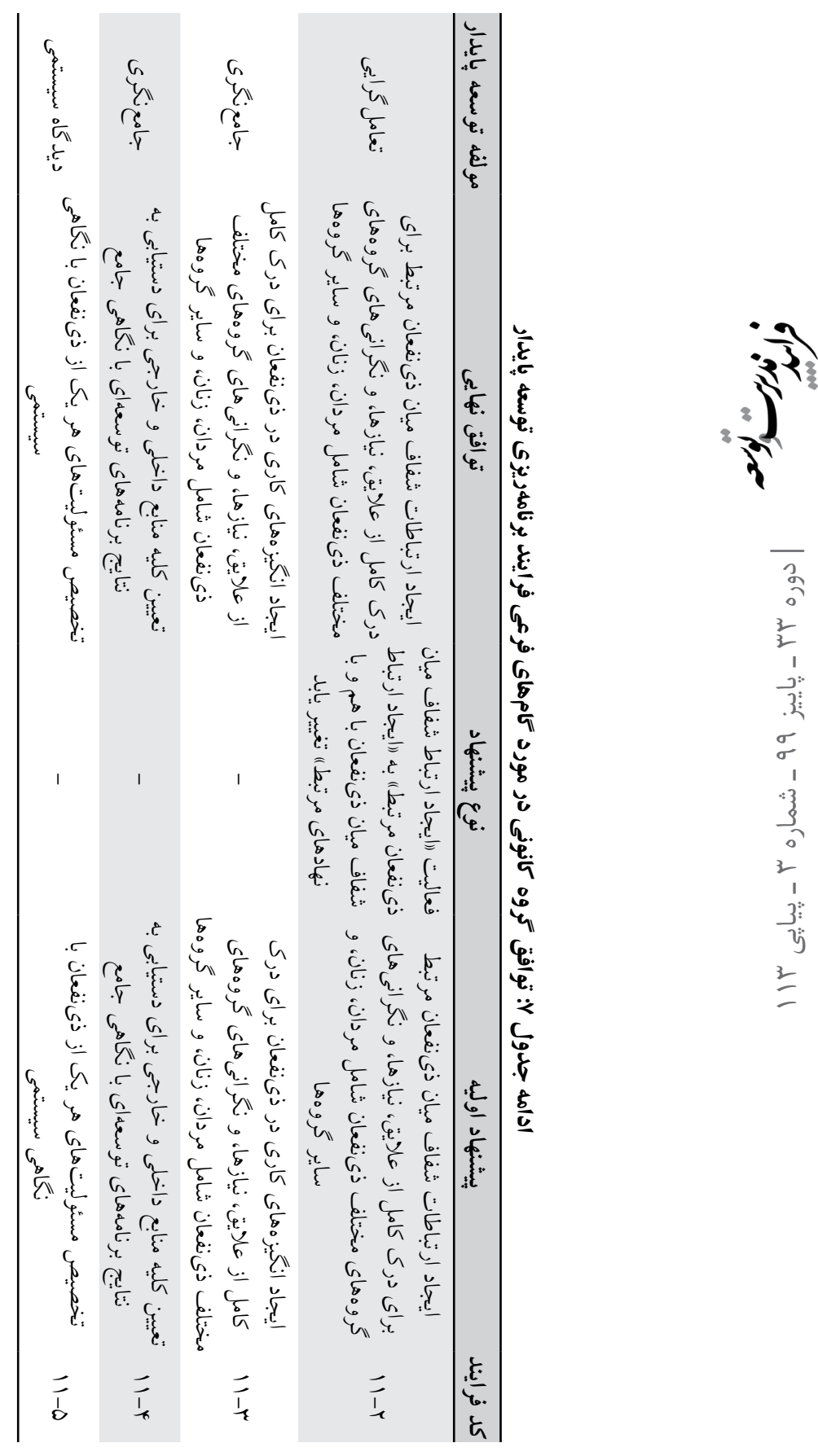

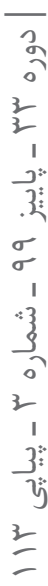


يس إز دريافت نظرهاى متخصصان برنامهريزى در قالب گروه كانونى، اقدام به سنجش روايى محتوايى

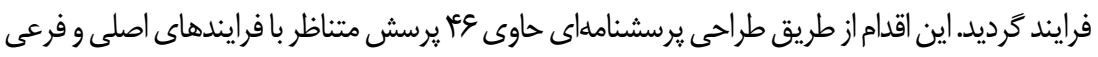

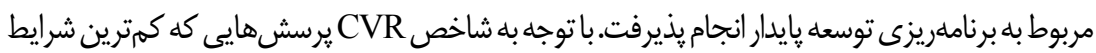

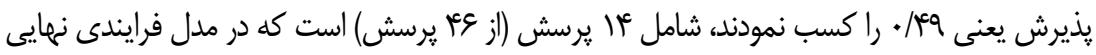

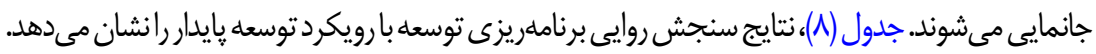

جدول ᄉ: يرسشهاى بر سشنامله به همراه مقدار CVR و نتيجهُ آنان

\begin{tabular}{|c|c|c|c|c|c|}
\hline نتيجه & CVR & برسش & نتيجه & CVR & يرسش \\
\hline رد & $\cdot / \cdot V$ & TY & يذيرش & $\cdot / N$ & 1 \\
\hline يذ يذيرش & $\cdot / N$ & rQ & נد & $\cdot / \& V$ & r \\
\hline ر & $\cdot / T$ & TG & يذيرش & $\cdot / N$ & $r$ \\
\hline رد & $\cdot / 4 V$ & TV & يذيرش & $\cdot 19$ & q \\
\hline נد & $-\cdot / 4 V$ & rA & נ) & $\cdot / A V$ & 0 \\
\hline رد & $\cdot / T$ & rq & رد & $\cdot / \cdot V$ & 4 \\
\hline رد & $-\cdot \cdot \cdot v$ & $r$. & يذيرش & .19 & v \\
\hline נد & $\cdot / \& V$ & r & נد & & $\wedge$ \\
\hline נد & $-\cdot / T$ & rT & נد & $-\cdot \cdot \cdot V$ & 9 \\
\hline يذيرش & $\cdot / A V$ & זr & رد & • & 1. \\
\hline נد & $\cdot / T$ & MY & يذيرش & $\cdot / N$ & 11 \\
\hline يذ يذيرش & $\cdot / N$ & ro & رد & $\cdot / \cdot V$ & Ir \\
\hline נد & r & rq & يذيرش & $\cdot / N$ & 14 \\
\hline נد & $\cdot / \& V$ & rV & رد & $-\cdot \cdot \cdot V$ & 14 \\
\hline يذ يذيرش & $\cdot / \Lambda V$ & щᄉ & يذّيرش & $\cdot 19$ & 10 \\
\hline رد & $\cdot / \cdot V$ & rq & رد & r & 19 \\
\hline رد & $\cdot / T$ & $r$. & يذيرش & $\cdot / N$ & IV \\
\hline נد & $\cdot / r$. & 41 & رد & $\cdot / \cdot V$ & 11 \\
\hline נد & $\cdot / A V$ & KY & נد & $-\cdot \cdot \cdot V$ & 19 \\
\hline נد & $\cdot / T$ & kr & נد & $-\cdot / T$ & $r$. \\
\hline 2 & $\cdot / \cdot V$ & kt & נد & • & YI \\
\hline يذ يذيرش & $\cdot / v r$ & is & נد & $\cdot / \cdot V$ & TY \\
\hline يذ يذش & $\cdot / \wedge \mathrm{V}$ & k9 & נد & $\cdot / 4 V$ & $r \mu$ \\
\hline
\end{tabular}


با بررسى نتايج نظر خبركان (در مرحله تحليل روايى) جنين استنباط مى گردد كه از ميان

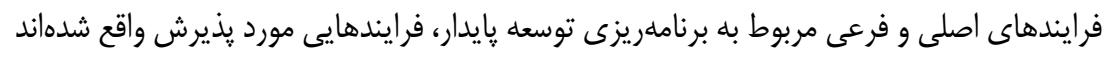

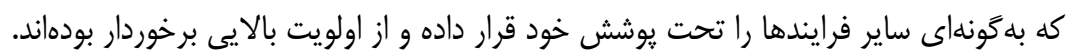

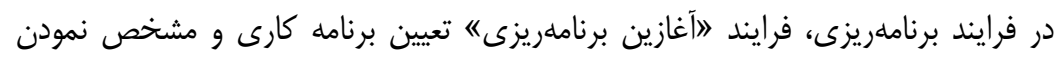

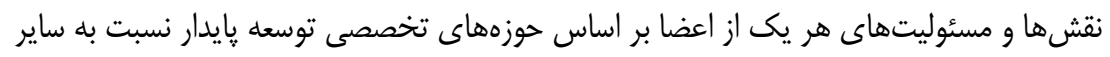

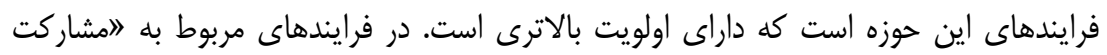

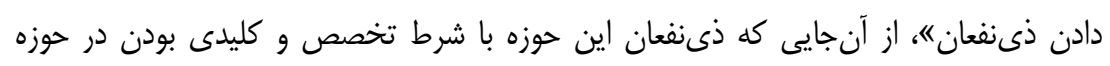

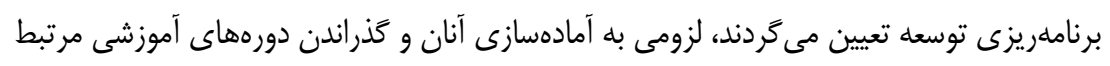

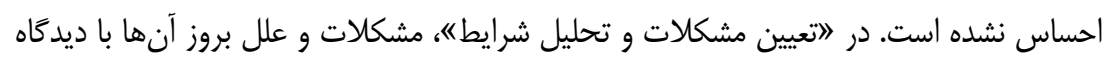

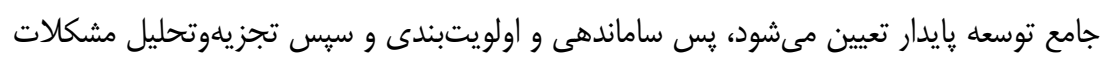

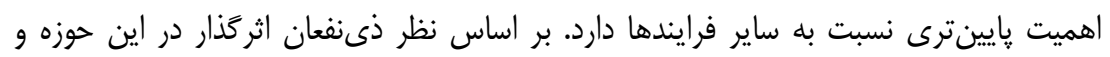

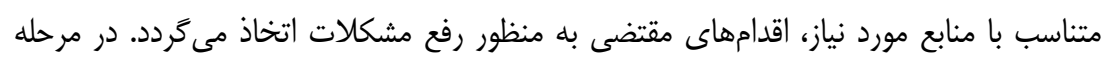

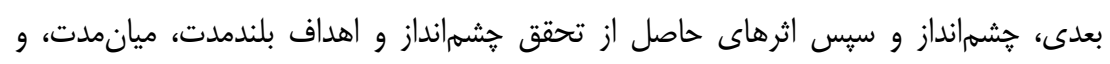

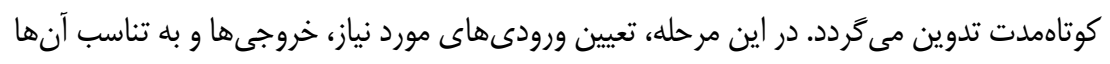

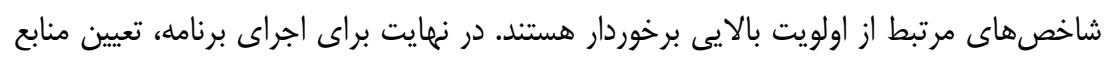

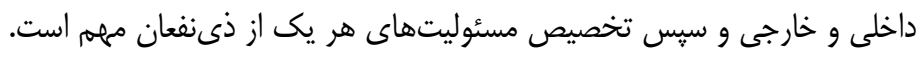

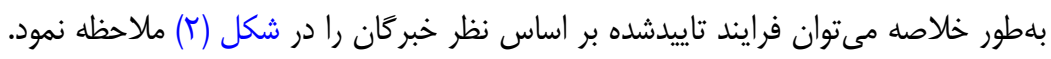

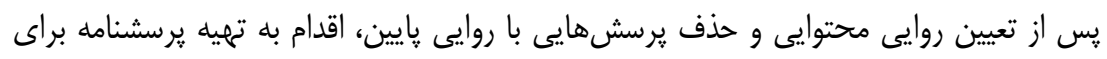

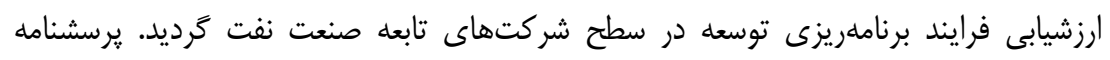

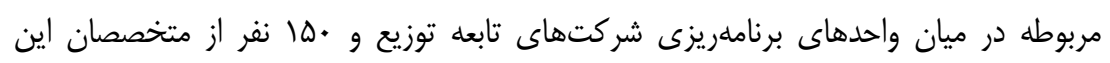

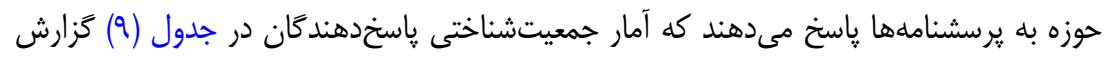
مىشود. به منظور تعيين بايايى يرسشنامه، آلفاى كرونباخ با استفاده از نرمافزار

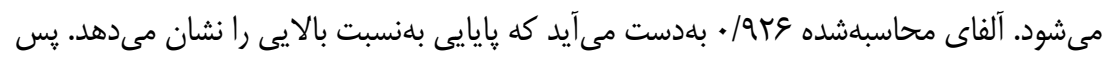

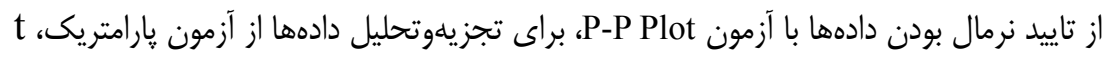
تكنمونهاى استفاده مىشود (جدول •(1). 
جدول 9: آمار جمعيت شناختى متخصصان حوزه برناملريزى شركتهاى تابعه صنعت نفت

\begin{tabular}{|c|c|c|c|c|c|c|c|c|c|c|c|c|c|}
\hline \multicolumn{3}{|c|}{ مدرك تحصيلى } & \multicolumn{4}{|c|}{ تجربه } & \multicolumn{4}{|c|}{ سن } & \multicolumn{3}{|c|}{ جنسيت } \\
\hline $\begin{array}{l}\hat{y} \\
\hat{y}\end{array}$ & $\begin{array}{ll}5 \\
3 \\
3 & 3 \\
3 & 3\end{array}$ & $\begin{array}{l}5 \\
3 \\
3 \\
3 \\
3\end{array}$ & $\begin{array}{l}\frac{y}{2} \\
\frac{1}{2} \\
\frac{2}{2}\end{array}$ & $\begin{array}{l}a \\
2 \\
\vdots \\
\underline{a}\end{array}$ & $\begin{array}{l}\leq \\
I\end{array}$ & $\frac{1}{1}$ & $\frac{1}{3}$ & $\begin{array}{l}\dot{9} \\
\frac{1}{2}\end{array}$ & $\begin{array}{l}2 \\
\frac{2}{1} \\
3 \\
3 \\
2\end{array}$ & $\begin{array}{l}\frac{y}{2} \\
\frac{1}{2} \\
\frac{1}{2}\end{array}$ & $\hat{\imath}$ & $\ddot{\jmath}$ & \\
\hline V & M & $\Delta Q$ & $r Q$ & ґی & 4. & TV & $r \cdot$ & iv & GY & rI & (r & IV & تعداد \\
\hline$k$ & $\Delta Q$ & $r v$ & IV & ro & $\psi$. & 11 & 14 & $\mu_{1}$ & 41 & If & 19 & 11 & درصد \\
\hline
\end{tabular}

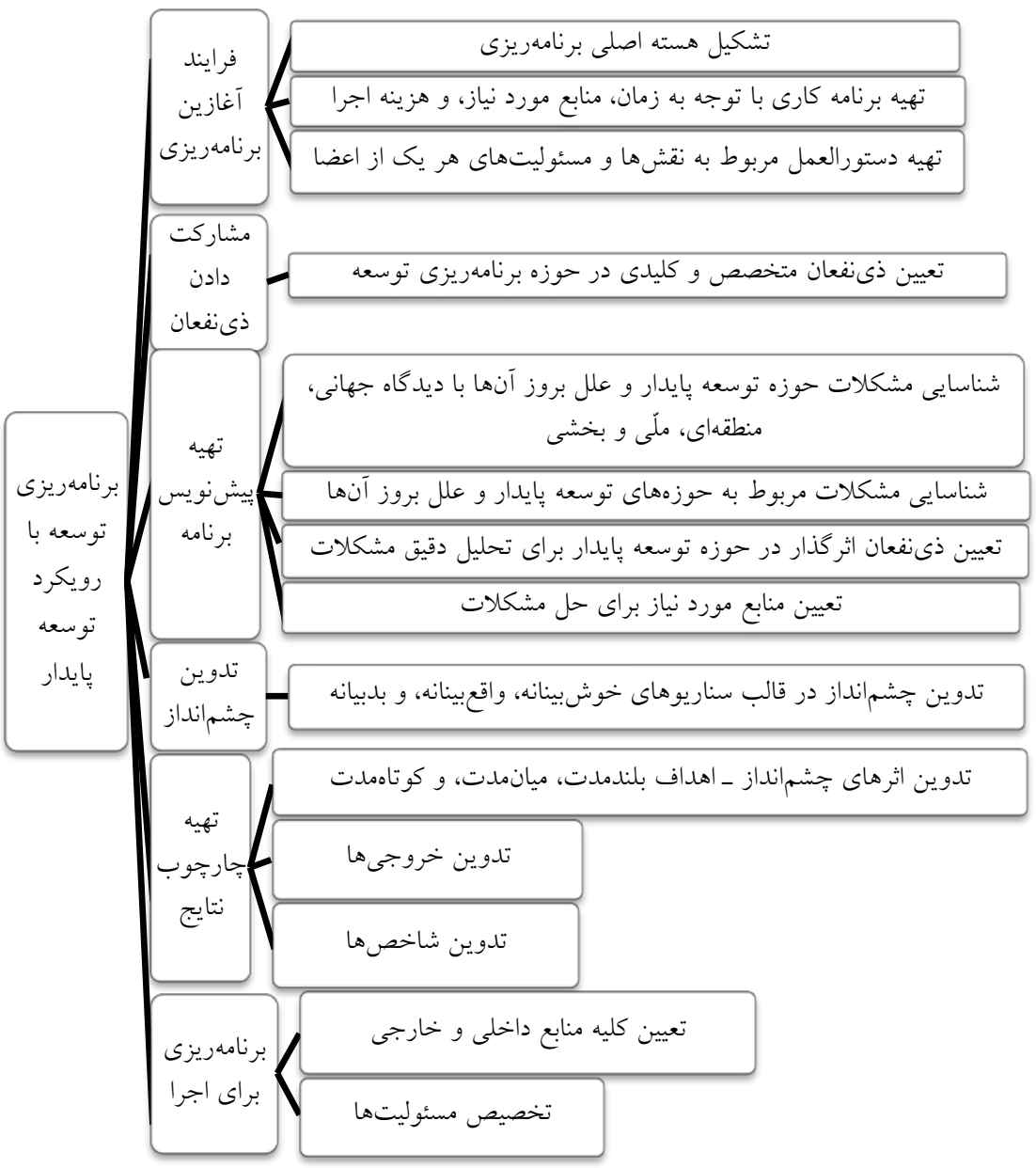

شكل r: نمودار درختى فرايند برنامهريزى توسعه با رويكرد توسعه پإيدار 
جدول • ا: آزمون پارامتريك t تككنمونهاى

\begin{tabular}{|c|c|c|c|c|c|c|}
\hline \multicolumn{7}{|c|}{ ارزش آزمون= r } \\
\hline \multicolumn{2}{|c|}{ دامنه اطمينان هه درصد } & \multirow{2}{*}{ تفاوت } & \multirow{2}{*}{ معنادارى سطح } & \multirow{2}{*}{ 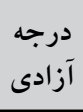 } & \multirow{2}{*}{$\mathbf{t}$} & \multirow{2}{*}{ متغير ها } \\
\hline كرانه بالا & كرانه بايين & & & & & \\
\hline . $/ 90 M \mid$ & $\cdot / \pi \cdot 99$ & $\cdot / \uparrow \wedge \cdots$ & $\cdot \cdots$ & 149 & $\Delta / \uparrow \wedge 1$ & تشكيل هسته اصلى برنامهريزى \\
\hline .19949 & ו ו וחת/• & $\cdot / 0 \ldots$ & $\cdot / \cdots$ & 1149 & $0 / 919$ & تهيه برنامه كارى \\
\hline$\cdot / D \wedge Y r$ & $\cdot /$ YIVA & $\cdot / 4 \ldots$ & $\cdot \cdots$ & 1149 & $\varphi / \mu T \Lambda$ & تهيه دستور العمل ها \\
\hline$\cdot / \Delta \Delta V$ & $\cdot / r \cdot r \cdot$ & $\cdot \kappa \wedge \cdot \cdots$ & $\cdot \cdots$ & 149 & F/YKY & تعيين ذىنفعان برنامهريزى \\
\hline • &.$/ .991$ & $\cdot /$ T494V & $\cdot \cdots r$ & 1149 & $r / l Q \Lambda$ & شناسايى مشكلات به تفكيك جغر افيا \\
\hline.$/ 4919$ & $\cdot /$ MAY & $\cdot \pi r \ldots$ & $\cdot / \cdots$ & 149 & $r / 9 \wedge r$ & شناسايى مشكلات مرتبط با موضوع \\
\hline . MAtit &.$/|r T|$ & $\cdot /$ TA99V & $\cdot \cdots$ & 1149 & $r / 949$ & تعيين ذىنفعان توسعه يايدار \\
\hline.$/ 9 V T \wedge$ & - TMOYA & 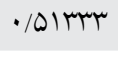 & $\cdot \cdots$ & 149 & $9 / 419$ & تعيين منابع حل مشكلات \\
\hline - MYTKV & $\cdot / \cdot \Delta \Delta r$ & $\cdot /$ TY... & $\cdot / 11$ & 149 & $r / D S V$ & تدوين جشمانداز \\
\hline$\cdot|x \cdot k|$ & .1 .949 & 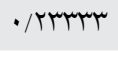 & $\cdot \cdots \wedge$ & 1149 & $r / V \cdot I$ & ت تدوين اهداف \\
\hline$\cdot$ • MVTH & $\cdot / \cdot T V V$ & $\cdot / r \cdots$ & 每 & 149 & r/TqR & تدوين خروجىها \\
\hline - /TYQS & $-\cdot / \cdot \wedge \Delta 4$ & $\cdot / \cdot \wedge \cdot \cdots$ & $\cdot / \mu \times 1$ & 1149 & $\cdot / 90 Y$ & تدوين شاخصها \\
\hline$\cdot / 419$. &.$/ .94$. & $\cdot /$ Tr.. & $\cdot \cdots \wedge$ & 149 & $r / 994$ & تعيين منابع اجراى برنامه \\
\hline - Mrupk &.$- / \cdot 1 k t$ &.$/ 19 \ldots$ & $\cdot / \cdot V T$ & 149 & $1 / \wedge \mid r$ & تخصيص مسئوليت ها \\
\hline
\end{tabular}

بنابراين مىتوان نتيجه گرفت كه تقريباً عم درصد فرايند برنامهريزى توسعه پايدار در صنعت نفت از سطح قابلقبولى برخوردار است.

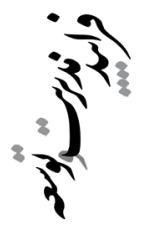

\section{بحث و نتيجه Fيرى}

يزوهش حاضر با هدف تعيين فرايندهاى اصلى و فرعى در برنامهريزى توسعه پايدار و ارزشيابى

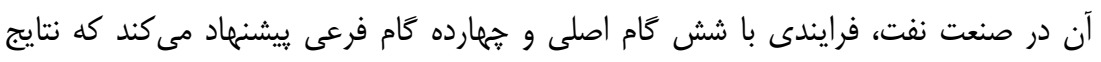

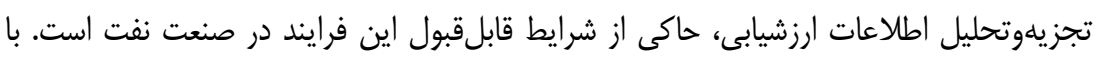

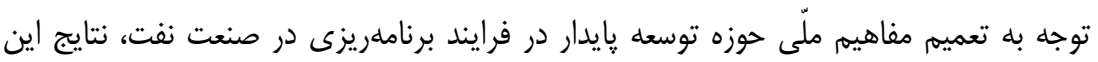
يزوهش مىتواند علاوه بر صنعت نفت در ساير دستخاههاى اجرايى مورد استفاده قرار گيرد. وضعيت فرايندهاى اصلى صنعت نفت در مقايسه با وضعيت ايدهآل و ميانگين در شكل (r) 
مشخص مىشود، كه نشان مىدهد كليه فرايندهاى اصلى برنامهريزى در صنعت نفت از وضعيت

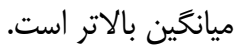

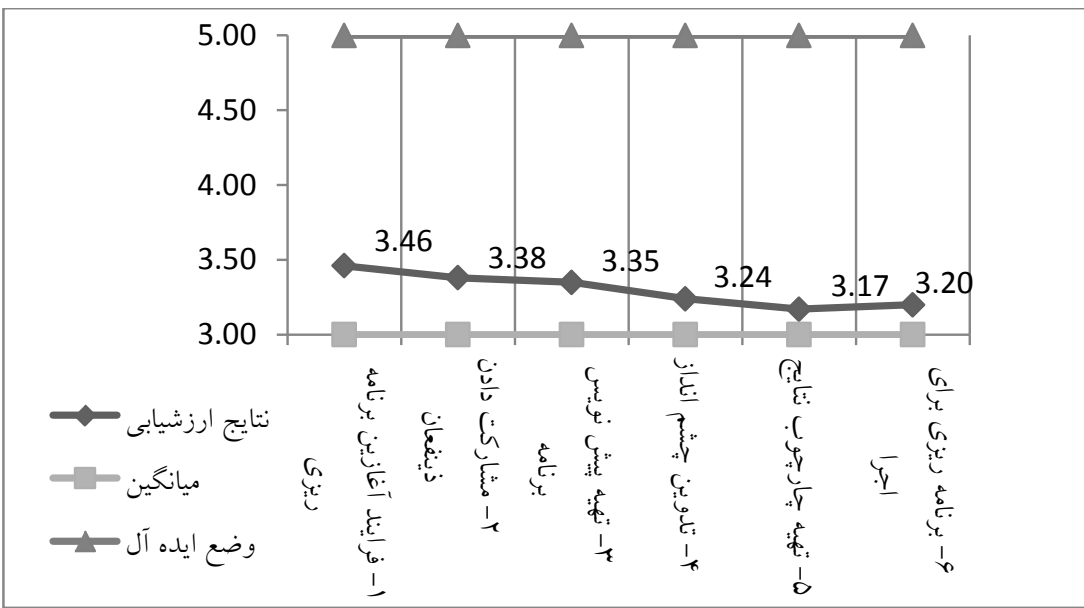

شكل "ז: نتيجه ارزشيابى فرايند برنامهريزى توسعه با رويكرد توسعه بايدار

با توجه به نتايج ارزشيابى فرايند برنامهريزى توسعه در صنعت نفت جنين استنباط مى

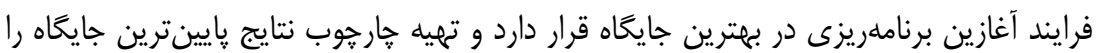

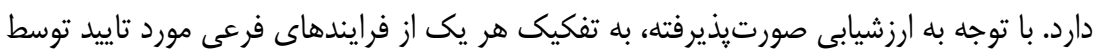
متخصصان حوزه برنامهريزى توسعه پايدار، فعاليتهاى زير از سطح قابلقبولى برخوردارند: • تشكيل هسته اصلى برنامهريزى شامل متخصصانى از حوزههاى مرتبط با توسعه يايدار (اقتصادى،

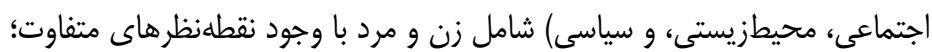
• تهيه برنامه كارى بر اساس زمان كل فرايند برنامهريزى، منابع مورد نياز و هزينه مرتبط، با در

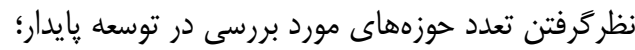

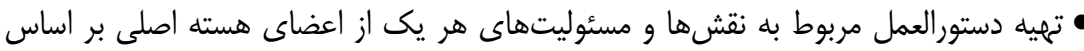
حوزههاى تخصصى مرتبط؛ • تعيين ذىنفعان متخصص كليدى در حوزه برنامهريزى توسعه، فارغ از نخاه جنسيتى و قومى براى توانمندسازى تمام گروههاى متخصص؛

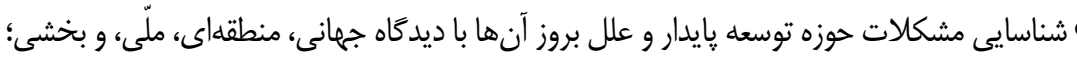


• شناسايى مشكلات مربوط به سياستها و محيط قانونى، هنجارهاى فرهنكى و اجتماعى، مشكلات مربوط به فاصله ميان ظرفيتهاى نهادى، مشكلات زيستمحيطى، و مسائل

$$
\text { اقتصادى و علل بروز آنها؛ }
$$

• تعيين ذى نفعان اثركذار در حوزه توسعه بايدار براى تحليل دقيق مشكلات؛

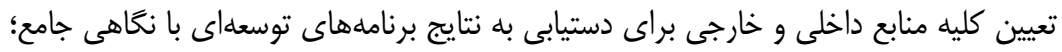

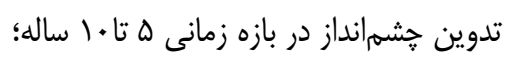

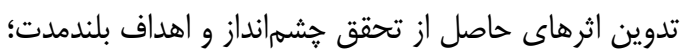

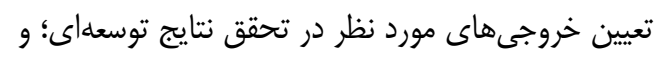

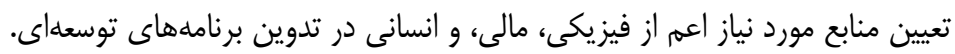

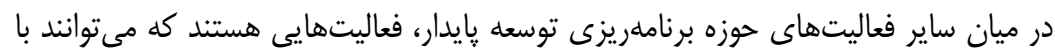

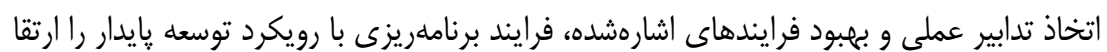

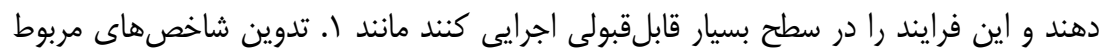

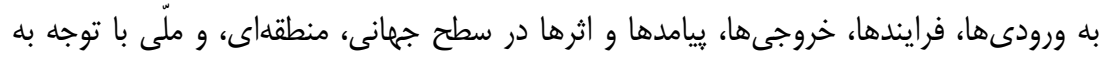

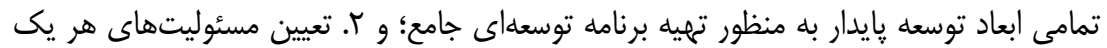

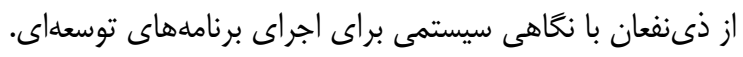

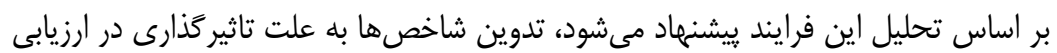

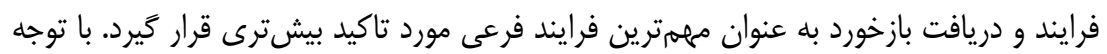

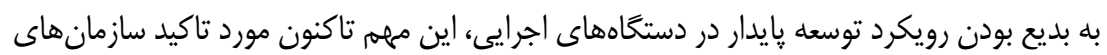

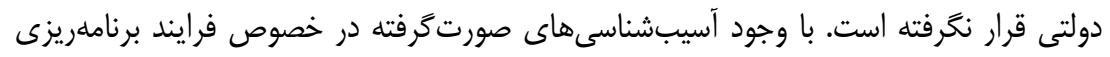

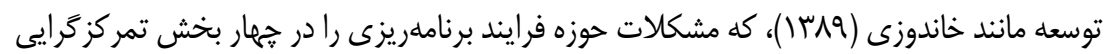
در برنامهنويسى و نبود مشاركت ذى نفعان، مسائل مربوط به زمانبندى فرايند برنامهنويسى، نحاه

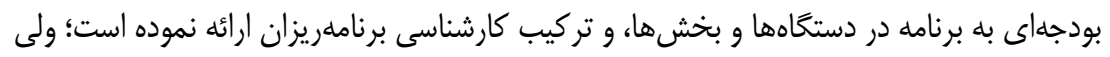

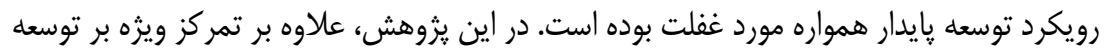

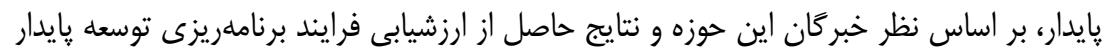

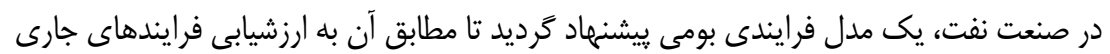
برناماريزى در دستخاههاى دولتى مبادرت كرد درد.

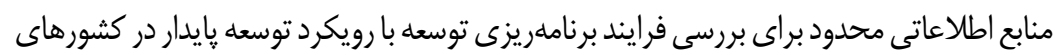

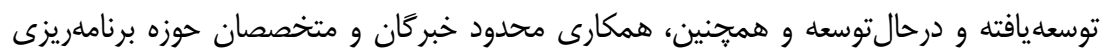


توسعه بايدار در سنجش سوء گيرى را مىتوان به عنوان محدوديتهاى اين بزوهش برشمرد.

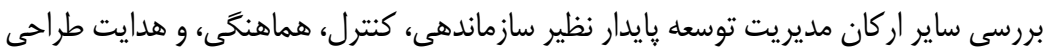

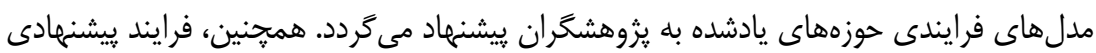
برنامهريزى توسعه پايدار قابليت ارزشيابى در ساير دستخاههاى اجرايى را داراست، تا بر اساس نتايج، اين فرايند بتواند به عنوان يك راهنما در تدوين برنامههاى توسعه پايدار مورد استفاده قرار كَيرد.

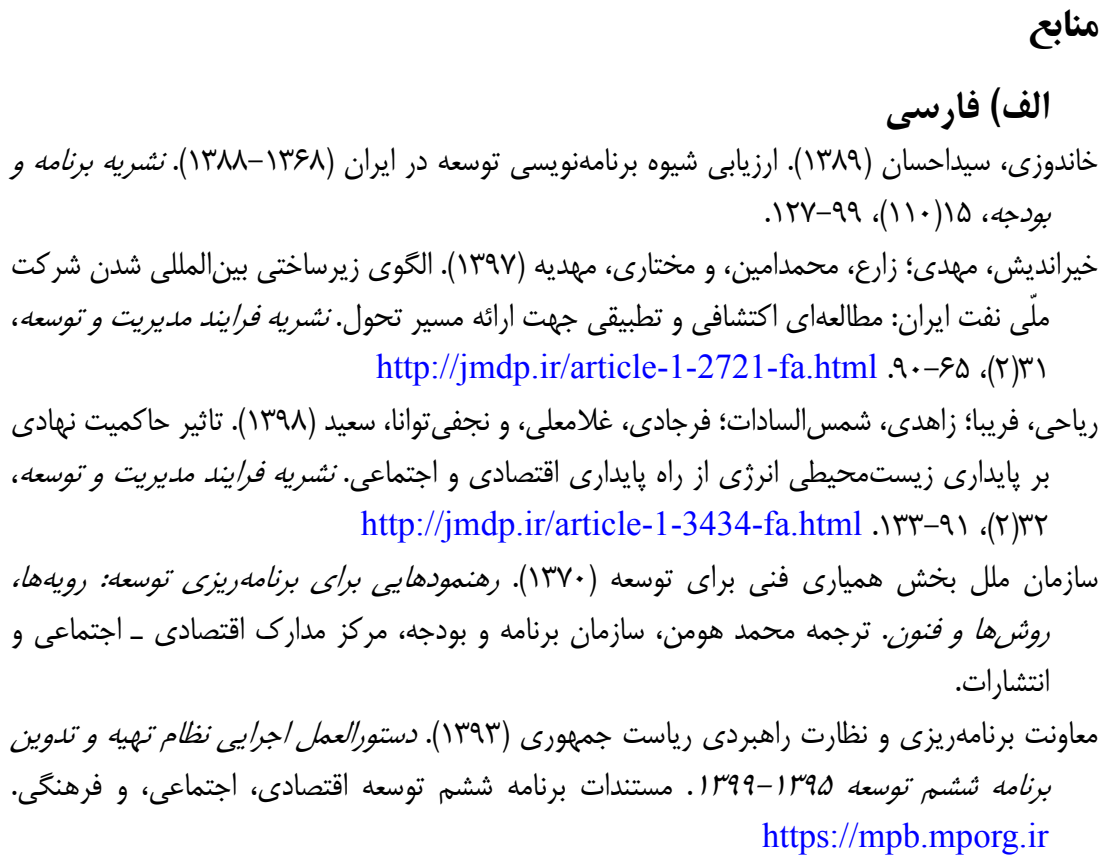

Bartle, J. R., \& Leuenberger, D. (2006). The Idea of Sustainable Development in Public Administration: Sage Publications A: Thousand Oaks, CA.

Boulanger, P.-M., \& Bréchet, T. (2005). Models for Policy-Making in Sustainable Development: The State of the Art and Perspectives for Research. Ecological Economics, 55(3), 337-350. https://doi.org/10.1016/j.ecolecon.2005.07.033. Brodhag, C., \& Talière, S. (2006). Sustainable Development Strategies: Tools for Policy Coherence. Paper Presented at the Natural Resources Forum. 
https://doi.org/10.1111/j.1477-8947.2006.00166.x.

Dernbach, J. C. (1998). Sustainable Development as a Framework for National Governance. Case Western Reserve Law, 49, 1.

Dernbach, J. C. (2003). Achieving Sustainable Development: The Centrality and Multiple Facets of Integrated Decision Making. Global Legal Studies, 10(1), 247-284. https://doi.org/10.2979/gls.2003.10.1.247.

Elliott, J. (2012). An Introduction to Sustainable Development: Routledge.

Emas, R. (2015). The Concept of Sustainable Development: Definition and Defining Principles. Brieffor GSDR, 2015.

Faucheux, S., Pearce, D., \& Proops, J. (1996). Models of Sustainable Development Edward Elgar: London.

Furtado, J. I. d. R., Belt, T., \& Jammi, R. (2000). Economic Development and Environmental Sustainability: Policies and Principles for a Durable Equilibrium: The World Bank.

Gills, B. K. (2002). Democratizing Globalization and Globalizing Democracy. The Annals of the American Academy of Political and Social Science, 581(1), 158-171.

Heady, F. (2001). Public Administration, a Comparative Perspective: CRC Press.

Hellström, D., Jeppsson, U., \& Kärrman, E. (2000). A Framework for Systems Analysis of Sustainable Urban Water Management. Environmental Impact Assessment Review, 20(3), 311-321. https://doi.org/10.1016/S0195-9255(00)00043-3.

Hrebik, S., Trebicky, V., \& Gremlika, T. (2006). Manual for Planning and Evaluation of SD at the Regional Level. Office of the Government of the Czech Republic.

Hughes, O. E. (2012). Public Management and Administration: An Introduction: Macmillan International Higher Education.

Imperatives, S. (1987). Report of the World Commission on Environment and Development: Our Common Future. Accessed Feb, 10.

Intergovernmental Panel on Climate Change (IPCC) (2007). Climate Change 2007: The Physical Science Basis, Contribution of Working Group I to the Fourth Assessment Report of the Intergovernmental Panel on Climate Change: Cambridge University Press.

Karlsson, S. (1999). Closing the Technospheric Flows of Toxic Metals: Modeling Lead Losses from a Lead-Acid Battery System for Sweden. Journal of Industrial Ecology, 3(1), 23-40. https://doi.org/10.1162/108819899569377.

Kirkpatrick, C., George, C., \& Curran, J. (2001). Development of Criteria to Assess the Efectiveness of National Strategies for Sustainable Development. Institute 
for Development Policy and Management, University of Manchester.

Lawshe, C. H. (1975). A Quantitative Approach to Content Validity. Personnel Psychology, 28(4), 563-575.

Levings, C. D. (2004). Knowledge of Fish Ecology and Its Application to Habitat Management. Fraser River Delta, British Columbia: Issues of an Urban Estuary, Geological Survey of Canada Bulletin, 567(1), 213-236.

Litfin, K. (1994). Ozone Discourses: Science and Politics in Global Environmental Cooperation: Columbia University Press.

Marinova, D., \& McGrath, N. (2005) Transdisciplinarity in Teaching and Learning Sustainability, in Banse, G., Hronszky, I., and Nelson, G. (eds), Rationality in an Uncertain World, 275-285, Edition Sigma, Berlin.

Meadows, D. H., Meadows, D. L., Randers, J., \& Behrens, W. W. (1972). The Limits to Growth. New York, 102(1972), 27.

Pearce, J. A., Freeman, E. B., \& Robinson Jr, R. B. (1987). The Tenuous Link between Formal Strategic Planning and Financial Performance. Academy of Management Review, 12(4), 658-675. https://doi.org/10.5465/amr.1987.4306718. Rao, P. (2000). Sustainable Development: Economics and Policy: Malden, Oxford. Redclift, M. (2002). Sustainable Development: Exploring the Contradictions: Routledge.

Saunders, M., Lewis, P., \& Thornhill, A. (2009). Research Methods for Business Students: Pearson Education.

Scriven, M. (1974). Evaluation Perspectives and Procedures. In Evaluation in Education, Popham, W. J., McCutchan Publishing Corp., 2526.

Speth, J. G. (2004). Red Sky at Morning: America and the Crisis of the Global Environment: Yale University Press.

State of Qatar (2014). National Development Planning and Implementation Human Development, Sustainable Development and National Well-being, New York. https://www.un.org.

Stillman, R. (2009). Public Administration: Concepts and Cases: Nelson Education. Stoddart, H. (2011). A Pocket Guide to Sustainable Development Governance. Stakeholder Forum. Paper Presented at the United Nations Conference on the Human Environment (1992). Rio Declaration on Environment and Development. Rio de Janiero, Brazil: United Nations.

Stufflebeam, D. L. (1971). The Use of Experimental Design in Educational Evaluation. Journal of Educational Measurement, 8(4), 267-274. https://doi.org/10.1111/j.1745-3984.1971.tb00936.x.

Todorov, V., \& Marinova, D. (2009). Models of Sustainability. Paper Presented at the Proceedings of MODSIM 2009 International Congress on Modelling and Simulation. 
Turco, R. P., Toon, O. B., Ackerman, T. P., Pollack, J. B., \& Sagan, C. (1983). Nuclear Winter: Global Consequences of Multiple Nuclear Explosions. Science, 222(4630), 1283-1292.

Tyler, R. W. (1942). General Statement on Evaluation. The Journal of Educational Research, 35(7), 492-501. https://doi.org/10.1080/00220671.1942.10881106.

UN (2001). Indicators of Sustainable Development: Guidelines and Methodologies: United Nations Publications.

UNDP (2011). The Evaluation Policy of UNDP. http://www.undp.org/eo/documents/Evaluation-Policy.pdf.

UNDP (2009). Handbook on Planning, Monitoring and Evaluation for Development Results. http://web.undp.org/evaluation/handbook/get_handbook.html.

Worthen, B. R., \& Sanders, J. R. (1987). Educational Evaluation: Alternative Approaches and Practical Guidelines: Longman Pub Group.

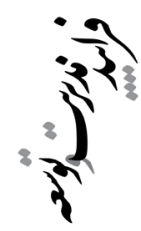

